\title{
Experimental Study of Solar Energy Based Water Purifier (SEBWP) of Single Slope Type by Incorporating N Similar Evacuated Tubular Collectors (ETCs) having Series Connection
}

\section{Sanjeev Kumar Sharma}

Amity University

\section{Ashis Mallick}

IIT (ISM): Indian Institute of Technology

Desh Bandhu Singh ( $\nabla$ dbsiit76@gmail.com )

GEU: Graphic Era Deemed to be University https://orcid.org/0000-0002-6092-5465

Gopal Nath Tiwari

IIT Delhi: Indian Institute of Technology Delhi

\section{Research Article}

Keywords: evacuated tubular collector, solar still, experimental study, exergo-enviro-economic analysis, energy metrics

Posted Date: June 11th, 2021

DOI: https://doi.org/10.21203/rs.3.rs-558075/v1

License: (9) This work is licensed under a Creative Commons Attribution 4.0 International License. Read Full License 


\section{Experimental study of solar energy based water purifier (SEBWP) of single slope type by} incorporating $\mathbf{N}$ similar evacuated tubular collectors (ETCs) having series connection

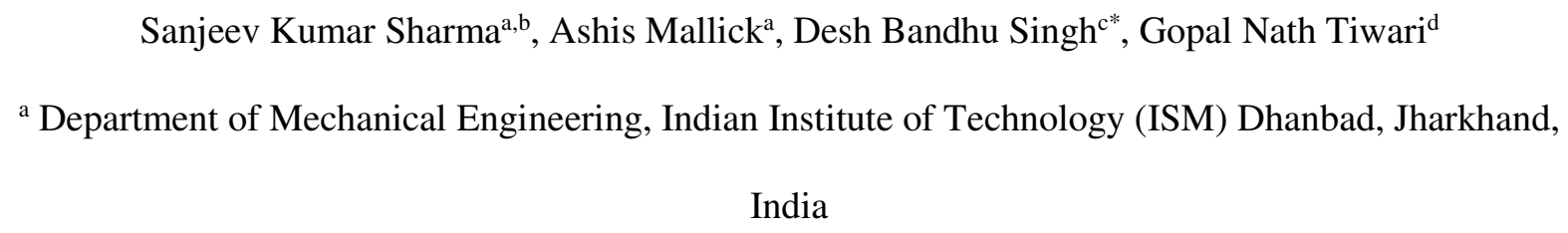

(1)

1

$$
\text { *Email id of corresponding author: dbsiit76@gmail.com/deshbandhusingh.me@geu.ac.in }
$$

\section{Abstract}

This research paper deals with the experimental investigation of solar energy based water purifier (SEBWP) of single slope type by incorporating $\mathrm{N}$ similar evacuated tubular collectors (ETCs) having series connection. Experimental investigation has been done for a year from August 2018 to July 2019. MATLAB has been used for evaluating performance parameters of the system followed by the validation of these results with their experimental values. A fair agreement has been found between theoretical and experimental values. Values of correlation coefficients for condensing glass temperature, water temperature and water yield have been found to be $0.9932,0.9928$ and 0.9951 respectively. Further, energy metrics, productivity, cost of producing one $\mathrm{kg}$ of fresh water, exergoeconomic and enviroeconomic parameters have been evaluated. Values of energy payback time, per $\mathrm{kg}$ cost of producing fresh water and exergy loss per unit Rs. have been evaluated to be 1.72 years, Rs. $0.95 / \mathrm{kg}$ and $0.128 \mathrm{kWh} / \mathrm{Rs}$. respectively. 
24 Key words: evacuated tubular collector; solar still; experimental study, exergo-enviro-economic 25 analysis, energy metrics

\section{Introduction:}

27 The design, analysis, installation and experimental study of solar energy based water purifier (SEBWP) of single slope type by incorporating $\mathrm{N}$ alike evacuated tubular collectors (ETCs) is a

29 pressing need at a time when the world is grappling with the current problem of fresh water scarcity. The purification of dirty water using solar energy is one of the best solutions for

31 providing the fresh water as it is environment friendly and does not need much technical

32 knowledge for its maintenance. The experimental study of solar energy based single slope water 33 purifier (SEBWP) by incorporating flat plate collector was presented by Rai and Tiwari (1983).

34 Since then, a lot of modifications in the design of SEBWP operating in active mode have been reported. Tripathi and Tiwari (2006) have studied SEBWP in active mode for different water 36 depth using solar fraction and concluded that the internal convective heat transfer coefficient 37 decreases with rising water depth due to increases in the sensible heat content of water mass. 38 Dimri et al. (2008) investigated performance of SEBWP in active mode by incorporating material of cover and it was concluded that the production of fresh water (yield) of reported system was higher with copper due to higher thermal conductivity of copper as compared to 41 glass and plastic.

42 The main drawback of SEBWP in active mode reported by Rai and Tiwari (1983), Tripathi and 43 Tiwari (2006), Dimri et al. (2008) was that SEBWP systems were not self sustainable as the 44 pump was running using conventional source of energy i.e. electrical energy from grid. These 45 systems could be made self sustainable by integrating photovoltaic panel with collector. Based 
on this concept, Kumar and Tiwari (2009) reported hybrid active SEBWP and compared results with SEBWP in passive mode. They revealed that the lesser production cost of fresh water from passive SEBWP was obtained due to less materials required for the production of passive SEBWP; however, the volume of fresh water production from passive SEBWP was very low and hence could not be commercialized. Further, Dev and Tiwari (2010) reported the thermal 51 modeling of PVT integrated SEBWP in active mode and concluded that the nonlinear 52 characteristic equation is better suited for performance analysis. Singh et al. (2011) studied PVT 53 integrated SEBWP of double slope type experimentally and it was reported that the yield was 1.4 54 times higher than the similar single slope set up due to better distribution of solar radiation 55 throughout the day in the case of double slope type. El-Sebaii et al. (2011) investigated SEBWP 56 by incorporating shallow solar pond and reported that the fresh wateryield was $68.12 \%$ more than 57 the simple SEBWP due to addition of heat by solar pond. Esfahani et al. (2011) have investigated 58 experimentally a special type portable SEBWP consisting of solar collector, thermoelectric output was comparable with other types of SEBWP. Arslan (2012) investigated experimentally

61 the different designs of SEBWP in active mode and concluded that the circular box type SEBWP 62 in active mode is most efficient and the highest daily efficiency was obtained as $68.1 \%$ due to 63 improvement in the design.

64 The fresh water yielding of SEBWP in active mode can be improved by replacing flat plate collectors by evacuated tubes as vacuum is present in such tubes which prevent heat loss by convection. Singh et al. (2013) and Kumar et al. (2014) developed thermal model for SEBWP of

67 single slope type by incorporating evacuated tubes in which end points of all pipe were slotted in 68 the basin of solar still in natural as well as forced modes of flow respectively. Sampatkumar et al. 
69 (2013) investigated SEBWP of single slope type integrated with evacuated tubes and it was 70 concluded that the yield of SEBWP was increased by $129 \%$ after integrating with evacuated 71 tubes due to additional heat addition by evacuated tubes to basin of SEBWP.

72 In another study, Hamadou and Abdellatif (2014) investigated SEBWP in active mode of 73 operation for sea water production under optimized condition and concluded that the fresh water 74 production is not the proportion of heat transfer fluid rate. Feilizadeh et al. (2015) investigated 75 experimentally multistage SEBWP in active mode by incorporating solar collectors and 76 concluded that the percentage increase in fresh water production decrease as the collector to 77 basin area ratio is increased because heated water is further heated. Taghvaei et al. (2015) 78 investigated SEBWP in active mode experimentally for five days continuously and concluded 79 that the overall fresh water production and efficiency decreased with the increases in brine depth 80 due to sensible heat absorbed by brine mass at increased brine depth. Sandeep et al. (2015) 81 studied SEBWP of single slope type in which extra condensing surface was provided and 82 concluded that the fresh water production in the improved design was $14.5 \%$ higher than the 83 conventional SEBWP of single slope type due to improvement in the condensation as the extra 84 condensation surface was provided. Singh et al (2016) investigated PVT integrated SEBWP of 85 single slope type and concluded that there was a fair conformity between values of theoretical 86 and experimental analyses with coefficient of correlation varying between 0.97 and 0.99 .

87 Issa and Chang (2017) studied SEBWP by integrating with evacuated tube in mixed mode 88 condition and it was concluded that the yield was better than the conventional SEBWP because 89 of heat addition by evacuated tubes in mixed mode connection to basin. Sahota and Tiwari 90 (2017) developed characteristic equation and reported an improvement in fresh water production 91 by $32 \%$ with $\mathrm{CuO}$ nanofluid over base fluid (water) due to increased absorptivity of nanofluid. 
92 Joshi and Tiwari (2018) investigated SEBWP in active mode of operation by incorporating heat

93 exchanger and reported that the fresh water yield cost was lowest for partially covered flat plate

94 collectors (FPC) with PVT; whereas, SEBWP integrated with fully covered PVT-FPC performed

95 best for electricity generation. Singh and Tiwari (2017), Singh $(2018,2019)$ and Singh and Al-

96 Helal (2018) performed the analytical study of basin type SEBWP by incorporating $\mathrm{N}$ alike

97 evacuated tubular collectors from energy, exergy, cost and energy metrics viewpoints and

98 concluded that SEBWP of double slope type performed better than SEBWP of single slope type

99 due to better distribution of solar energy throughout the day in the case of double slope type.

100 Kumar et al. (2018) investigated SEBWP operating in active mode experimentally and 101 concluded that the fresh water production from SEBWP operated in active mode was six times 102 more than the SEBWP in passive mode due to addition of more heat by collectors and increased 103 temperature difference between water surface and condensing cover as the condensing cover was 104 cooled. Gupta et al. (2018) developed the distinctive equation for SEBWP of single slope type by 105 incorporating CPC which was fully covered with PV for the same packing factor as that of 106 partially covered and it was reported that the instantaneous efficiency of the system containing 107 CPC with full coverage of PV was better than SEBWP consisting of partially covered PVT-CPC 108 due decreased top loss. Elsheikh et al. (2019) reported the application of artificial neural network 109 for different solar energy devices for optimization and prediction of performance parameters and 110 reviewed the work on solar energy devices. Elbar et al. (2019) investigated SEBWP of single 111 slope type by integrating PV and it was reported that the yield obtained was higher by $31.48 \%$ for 112 the PV integrated SEBWP over conventional SEBWP because PV acted as reflector which 113 allows more solar energy into the SEBWP. Feilizadeh et al. (2019) studied thermosyphon 114 SEBWP in active mode with improved condenser and concluded that the increase in the 
115 production of fresh water was $46 \%$ higher with improved condenser due to the difference of 116 partial vapor pressure between the water surface and condenser surface. Bait (2019) reported the 117 experimental study of SEBWP of double slope type by incorporating tubular solar collector and 118 concluded that the annual production was $35.73 \%$ more over the conventional SEBWP due to 119 compact design of collector. Sharshir et al. (2019) conducted an experimental analysis of a 120 pyramid-type SEBWP incorporating evacuated tubes and filled with nanofluid and concluded 121 that the modified system produced $64.5 \%$ more fresh water than the traditional SEBWP due to 122 improved fluid properties.

123 Essa et al. (2020) studied SEBWP operating in active mode using artificial neural network and 124 reported that Hawks Optimizer - artificial neural network was the most suitable for forecasting 125 the production of fresh water by active mode operated SEBWP. Parsa et al. (2020) reported the 126 effect of variation of water depth on SEBWP powered by photovoltaic and concluded that the 127 fresh water yield was $42.5 \%$ more if the depth was raised to $70.23 \%$ (from 3871 to 13005 ) due to 128 increased radiation, decreased atmospheric pressure and ambient air temperature. Hassan (2020) 129 investigated SEBWP experimentally by incorporating parabolic trough collector and concluded 130 that maximum freshwater production increases by about $6 \%$ in case of using double slope type 131 than the similar single slope set up. Tiwari et al. (2020) have reported the outcome of condensing 132 cover effect on PVT-CPC integrated conical solar still performance and it was found that the 133 production of fresh water (yield) of active conical SEBWP is higher than conventional SEBWP 134 due to increased condensing cover surface area. Shoeibi et al. (2020) studied SEBWP of double 135 slope type by incorporating thermoelectric cooling and heating and concluded that due to the 136 increased water temperature in the modified solar still, the yield of the modified solar still was 13776.4 percent higher than the traditional SEBWP of double slope type. Kumar et al. (2020) 
138 reported the effect of variation of number of collectors on the environmental parameter of

139 SEBWP of single slope type and concluded that due to an increase in the amount of heat added

140 to the SEBWP basin, the value of carbon credit increased with the number of collectors. Further,

141 Singh et al. (2020) examined the impact of mass flow rate variation on the life cycle conversion

142 efficiency of a single slope SEBWP and concluded that as the mass flow rate decreased, the

143 system's life cycle conversion efficiency improved because fluid flowing through collector tubes

144 had more time to consume solar energy. Shehata et al. (2020) investigated ultrasonic humidifier

145 augmented SEBWP with evacuated collector experimentally and concluded that concluded that

146 the ultrasonic humidifier improved the productivity by $44 \%$ due to circulation of water between

147 solar still and evacuated collector.

148 From the extant research study, it has been found that the theoretical study of SEBWP of single

149 slope type coupled with $\mathrm{N}$ alike ETCs has been carried out by incorporating different parameters

150 like exergoeconomic, enviroeconomic, energy metrics, productivity and efficacies. However, no

151 researcher in the world has worked on an experimental study of SEBWP integrating ETCs. The

152 system under study is different from the system reported by Singh et al. (2013), Kumar et al.

153 (2014) Sampatkumar et al. (2013) and Issa and Chang (2017) in the sense that they used

154 evacuated tubes; whereas, the ETC in the present study consists of U shaped copper tubes

155 inserted in evacuated tubes. Further, experimental study is a must of any renewable system as it

156 helps in realization of particular technology/system. Hence, experimental study of SEBWP

157 integrated with evacuated tubular collectors has been carried out and reported in this research

158 paper. The main objectives can be stated as follows:

159 i. Experimental validation of theoretical results with experimental values for SEBWP of 160 single slope type integrated with $\mathrm{N}$ alike ETCs for $\mathrm{N}=13$. 
ii. Cost estimation of producing unit $\mathrm{kg}$ of fresh water, productivity and exergoeconomic parameter for SEBWP of single slope type integrated with ETCs on the basis of experimental data for $\mathrm{N}=13$.

iii. Evaluation of energy metrics and enviroeconomic parameter of SEBWP integrated with ETCs taking experimentally collected data as basis.

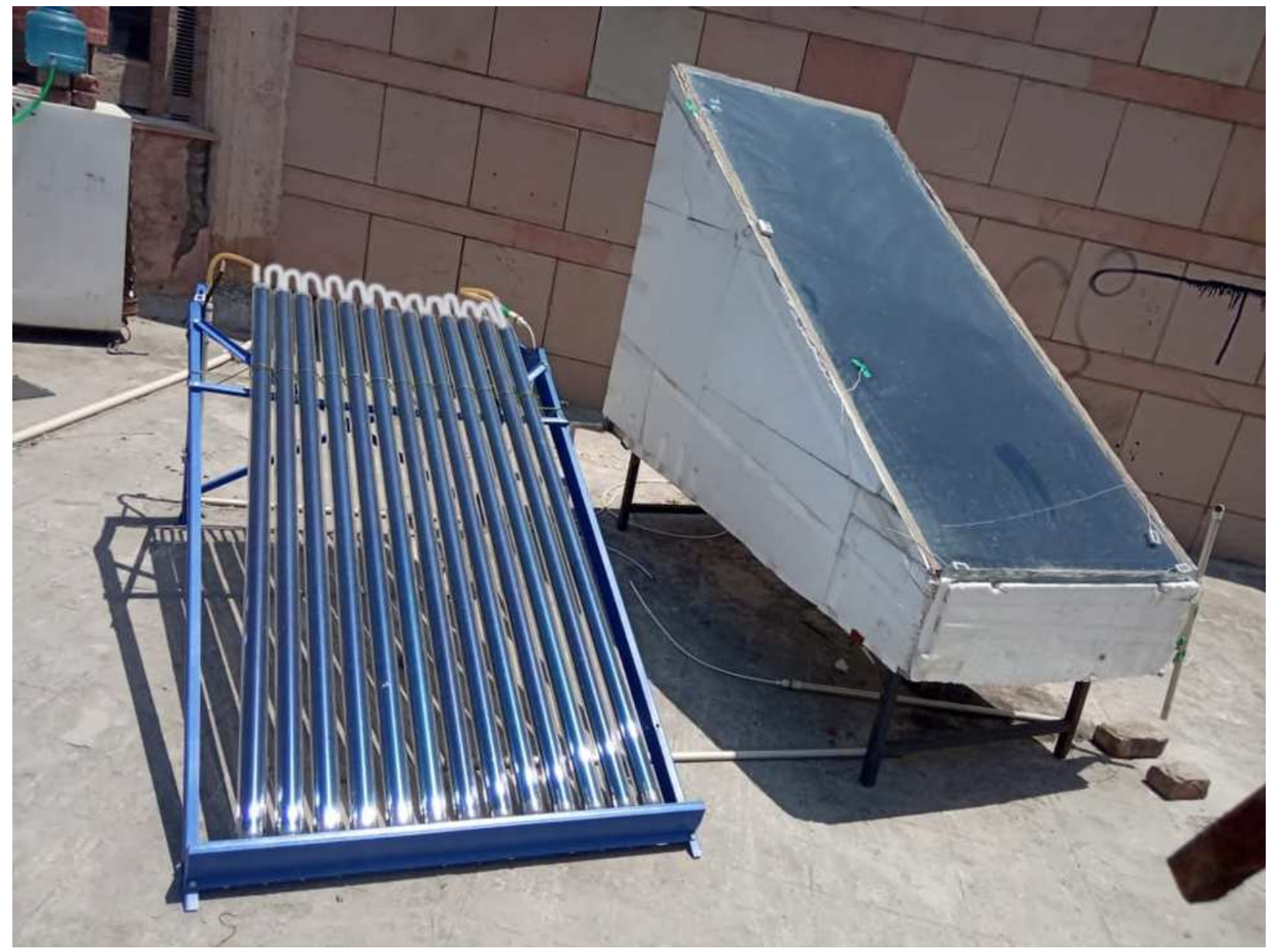

Fig. 1: Experimental setup of SEBWP of single slope type integrated with evacuated tubular collectors

\section{Experimental setup of SEBWP of single slope type integrated with $\mathrm{N}$ alike ETCs}

The specification of SEBWP of single slope type integrated with $\mathrm{N}$ alike ETCs has been revealed as Table 1. Fig. 1 represents the experimental setup of SEBWP of single slope type integrated 
173 with evacuated tubular collectors. It consists of series connected evacuated tubular collectors, 174 pump and single slope type SEBWP. The experimental setup incorporates series connected 175 evacuated tubular collectors (13 in number) to SEBWP of single slope type with the help of 176 pump. Pump gets its power from grid for its working. Collectors are connected in series with the 177 help of insulated pipe, the output of last collector is connected to basin through insulated pipe 178 and input to the first collector has also been taken through insulated pipe from pump which takes 179 water from basin through insulated pipe. One collector has a surface area of $0.0864 \mathrm{~m}^{2}$ hence the 180 total surface area of the sequence of evacuated tubular collectors is $1.1232 \mathrm{~m}^{2}$. The evacuated 181 tubular collector consists of two concentric cylinders made up of glass and vacuum is provided 182 between these two concentric glass cylinders which prevents heat loss by convection. So, heat 183 loss is lower in this collector in comparison to other collectors like flat plate collector and 184 compound parabolic concentrator collector where heat loss takes place by convection also. The 185 inner glass cover's inner surface is painted black to serve as an absorber. A copper U-tube has 186 been inserted inside the inner glass cylinder. Copper tube has been taken due to its high thermal 187 conductivity property.

188 The evacuated tubular collectors are connected in series to a single slope type SEBWP basin 189 with $2 \mathrm{~m} \mathrm{x} 1 \mathrm{~m}\left(2 \mathrm{~m}^{2}\right)$ basin area. It was fabricated using galvanized iron (GI) sheet. The inside 190 surface of GI sheet was painted black to absorb solar radiation. The outer surface was covered 191 with glass wool and thermocol. The top surface of single slope type SEBWP was covered with 192 glass having angle of inclination as $15^{\circ}$ as the setup was designed for summer season viewpoint. 193 The glass was fixed with help of iron clamp and rubber placed in between iron frame and glass. 194 The sealing was done using window-putty with an aim to avoid seepage of vapor. 
Table 1: Specifications of solar energy based water purifier (SEBWP) of single slope type by incorporating $\mathrm{N}$ number of series connected evacuated tubular collectors (ETCs)

\begin{tabular}{|c|c|c|c|}
\hline \multicolumn{4}{|c|}{ SEBWP of single slope type } \\
\hline Component & Specification & Component & Specification \\
\hline Length & $2 \mathrm{~m}$ & Cover material & Glass \\
\hline Width & $1 \mathrm{~m}$ & Orientation & South \\
\hline Inclination of glass cover & $15^{\circ}$ & Thickness of glass cover & $0.004 \mathrm{~m}$ \\
\hline Height of smaller side & $0.14 \mathrm{~m}$ & $K_{g}$ & $0.816 \mathrm{~W} / \mathrm{m}-\mathrm{K}$ \\
\hline Material of body & GI Sheet & Thickness of insulation & $0.1 \mathrm{~m}$ \\
\hline Material of stand & GI & $K_{i}$ & $0.166 \mathrm{~W} / \mathrm{m}-\mathrm{K}$ \\
\hline \multicolumn{4}{|c|}{ ETC } \\
\hline Component & Specification & Component & Specification \\
\hline Type and no. of collectors & ETC , 13 & $\alpha_{p}$ & 0.8 \\
\hline DC motor rating & $12 V, 24 W$ & $F^{\prime}$ & 0.968 \\
\hline Radius of inner copper tube & $0.0125 \mathrm{~m}$ & $\tau_{g}$ & 0.95 \\
\hline Thickness of copper tube & $0.0005 \mathrm{~m}$ & $K_{g}\left(W m^{-1} K^{-1}\right)$ & 1.09 \\
\hline Outer radius of outer glass tube of & & Angle of ETC with & \\
\hline evacuated coaxial glass tube & $0.024 \mathrm{~m}$ & horizontal & $30^{\circ}$ \\
\hline Inner radius of inner glass tube of & & Length of each copper & \\
\hline evacuated coaxial glass tube & $0.0165 \mathrm{~m}$ & tube & $1.8 \mathrm{~m}$ \\
\hline \multicolumn{4}{|l|}{ Thickness of outer/inner glass tube } \\
\hline of evacuated coaxial glass tube & $0.002 \mathrm{~m}$ & & \\
\hline
\end{tabular}

199 The short wavelength solar radiation reaches the water surface after passing through the 200 condensing cover where a part of energy is reflected by water and the remainder is transmitted to 201 the basin liner after being absorbed by water. The basin liner transmits the absorbed energy to 202 the water as it is insulated from outside, and loss of heat is not possible to outside. The 
203 temperature of the water increases and within the solar still the heat transfer from the water

204 surface to condensing cover takes place via convection, radiation and evaporation. Water vapor

205 condenses at the inside surface of the cover after losing latent heat of condensation, and film

206 wise condensation is ensured by careful cleaning of the surface so that condensate can be

207 collected as it will trickle down due to the component of gravity force. Drop wise condensation

208 has negative effect on the performance of solar still as it will not allow the solar radiation to pass

209 through it i.e., it will act as opaque surface to incoming solar radiation. The heat accumulated at

210 the condensing glass surface is dissipated to the surrounding by means of convection and

211 radiation and it strongly depends on the wind speed or water flow rate if additional arrangement

212 is made to dissipate it in the form of water flow over condensing cover over a certain time

213 period. A bottom opening has also been created to allow the sediments to be flushed out after a

214 period of time. Digital thermocouples were used to measure the different temperatures.

\section{3. Instrumentation}

217 Measuring instruments were used for the measurement of different parameters. The velocity of 218 air blowing was measured using the digital anemometer model of LUTRON AM-4201. Solar

219 radiation was assessed on an hourly basis with the aid of a Solarimeter with a minimum count of

$22020 \mathrm{~W} / \mathrm{m}^{2}$.The various temperatures were measured using digital thermocouple. The calibrated 221 mercury thermometer was used for the measurement of atmospheric temperature. The 222 measurement of distilled water was done using measuring flask. 
225 Table 2: Variation of different parameters of SEBWP of single slope type integrated with 226 evacuated tubular collectors at $0.09 \mathrm{~m}$ water depth for 29 April 2019

\begin{tabular}{cccccccc}
\hline $\begin{array}{c}\text { Time } \\
(\mathrm{h})\end{array}$ & $\begin{array}{c}\mathrm{I}_{\mathrm{c}} \\
\left(\mathrm{W} / \mathrm{m}^{2}\right)\end{array}$ & $\begin{array}{c}\mathrm{I}_{\mathrm{s}} \\
\left(\mathrm{W} / \mathrm{m}^{2}\right)\end{array}$ & $\begin{array}{c}\mathrm{V}_{\mathrm{a}} \\
(\mathrm{m} / \mathrm{s})\end{array}$ & $\begin{array}{c}\mathrm{T}_{\mathrm{a}} \\
\left({ }^{\circ} \mathrm{C}\right)\end{array}$ & $\begin{array}{c}\mathrm{T}_{\mathrm{w}} \\
\left({ }^{\circ} \mathrm{C}\right)\end{array}$ & $\begin{array}{c}\mathrm{T}_{\mathrm{gi}} \\
\left({ }^{\circ} \mathrm{C}\right)\end{array}$ & $\begin{array}{c}\text { Yield } \\
(\mathrm{kg} / \mathrm{h})\end{array}$ \\
\hline $8: 00$ & 420 & 440 & 3.40 & 30.0 & 34.0 & 32.0 & 0.000 \\
$9: 00$ & 600 & 640 & 1.50 & 32.0 & 39.3 & 33.5 & 0.085 \\
$10: 00$ & 780 & 820 & 1.20 & 33.0 & 45.6 & 34.7 & 0.098 \\
$11: 00$ & 900 & 920 & 2.20 & 34.6 & 52.2 & 40.4 & 0.380 \\
$0: 00$ & 960 & 980 & 1.70 & 36.0 & 60.5 & 46.5 & 0.687 \\
$13: 00$ & 980 & 1020 & 0.90 & 37.5 & 69.2 & 56.4 & 0.982 \\
$14: 00$ & 960 & 1000 & 1.00 & 39.5 & 78.2 & 65.5 & 1.125 \\
$15: 00$ & 880 & 920 & 1.00 & 39.0 & 83.4 & 73.3 & 1.458 \\
$16: 00$ & 760 & 780 & 2.10 & 39.4 & 89.7 & 78.5 & 1.615 \\
$17: 00$ & 600 & 600 & 1.20 & 37.0 & 91.4 & 81.3 & 1.760 \\
$18: 00$ & 320 & 340 & 1.60 & 36.8 & 85.2 & 77.2 & 1.268 \\
$19: 00$ & 0 & 0 & 1.30 & 35.3 & 80.4 & 70.3 & 0.988 \\
$20: 00$ & 0 & 0 & 1.10 & 35.0 & 76.7 & 63.4 & 0.790 \\
$21: 00$ & 0 & 0 & 0.00 & 34.0 & 70.3 & 58.4 & 0.578 \\
$22: 00$ & 0 & 0 & 0.90 & 34.2 & 68.2 & 55.5 & 0.415 \\
$23: 00$ & 0 & 0 & 0.30 & 28.5 & 65.4 & 50.4 & 0.400 \\
$24: 00$ & 0 & 0 & 0.00 & 27.2 & 61.2 & 48.5 & 0.320 \\
$1: 00$ & 0 & 0 & 0.80 & 27.4 & 60.4 & 47.2 & 0.225 \\
$2: 00$ & 0 & 0 & 0.90 & 26.3 & 59.4 & 44.5 & 0.215 \\
$3: 00$ & 0 & 0 & 1.00 & 25.4 & 54.9 & 42.5 & 0.200 \\
$4: 00$ & 0 & 0 & 1.20 & 26.2 & 52.5 & 40.3 & 0.200 \\
$5: 00$ & 0 & 0 & 1.30 & 26.5 & 51.6 & 39.8 & 0.200 \\
$6: 00$ & 0 & 0 & 2.20 & 25.6 & 50.3 & 37.5 & 0.115 \\
$7: 00$ & 0 & 0 & 1.80 & 28.4 & 48.5 & 36.5 & 0.100 \\
\hline
\end{tabular}

227

\section{4. Methodology}

229 The experiment was carried out on the roof of Galgotias College of Engineering and 230 Technology's Mechanical Block in Greater Noida, Uttar Pradesh, India. The data for the typical 231 day (April 29, 2019) have been presented as Table 2. The basin of single slope type SEBWP was 232 filled with underground water $24 \mathrm{~h}$ prior to the starting of the experimentation for establishing a 233 steady state condition prior to the start of the experiment. The experiment began at 8 A.M. local 
234 time and lasted until 7 A.M. the next day. Solarimeter was used to measure the solar intensity on 235 the surface of the SEBWP and the evacuated solar collector. The data for the different 236 parameters were collected for $24 \mathrm{~h}$. Different parameters for which data were collected are as 237 follows:

238 i. Basin water temperature

239 ii. Inner surface glass temperature

240 iii. Global radiation falling on the surface of SEBWP and collector

241 iv. Temperature of blowing air

242 v. Distillate output on per hour basis

243 The observation on the hourly basis has been presented as Table 2.

\section{5. Thermal modeling}

245 The thermal modeling of SEBWP of single slope types by incorporating $\mathrm{N}$ alike ETCs involves 246 the writing of equation taking energy balancing as the base for all parts of the system followed 247 by simplification. The objective of simplification of equations obtained from balancing energy is 248 to express the unidentified parameters in terms of known parameters like solar intensity, 249 atmospheric temperature and constants. The water temperature, inner condensing glass cover 250 temperature and fresh water yield on hourly basis are developed as a function of solar intensity, 251 ambient temperature and heat transfer coefficients. When writing energy balance equations, the 252 following assumptions are made to simplify the complex situation:

253 i. The vapor leakage in SEBWP is neglected.

254 ii. Solar distiller unit's water depth is constant. The change in distilled water yield is 255 very small when the water depth changes thus change in depth can be neglected. 
270

271

272

273

274 Where $r=$ Radius of copper tube.

275 Using equations (1) and (2), the water temperature at the first collector's outlet can be expressed 276 as

iii. The brackish water held in the basin does not develop layers.

iv. The heat capacity of the bottom and side insulating material along with condensing glass cover is neglected.

v. The condensation with film type characteristic occurs at inside plane of condensing cover. Careful cleaning of the inner surface of the glass ensures film-wise condensation and by providing small angle to the condensing cover favors it. The component of gravity force along the condensing cover will allow the condensate to trickle down along the surface and finally collected in measuring jar.

vi. All evacuated collectors are identical.

Following Singh et al. (2017), development of expression for the temperature from the last collector and thermal energy addition to the basin water is done by energy balancing for receiver surface and water flowing in the copper tubes.

\subsection{For evacuated tubular collectors}

\subsubsection{For the absorber surface}

$\alpha \tau^{2} I(t) 2 R d x=\left[F^{\prime} h_{p f}\left(T_{p}-T_{f}\right)+U_{t p a}\left(T_{p}-T_{a}\right)\right] 2 R d x$

Where $F^{\prime}$ denotes collector efficiency factor.

\subsubsection{For fluid flowing through tube}

$\dot{m}_{f} C_{f} \frac{d T_{f}}{d x} d x=F^{\prime} h_{p f}\left(T_{p}-T_{f}\right) 2 \pi r d x$ 
$277 \quad T_{f o 1}=\frac{\left(A F_{R}(\alpha \tau)\right)_{1}}{\dot{m}_{f} C_{f}} I(t)+\frac{\left(A F_{R} U_{L}\right)_{1}}{\dot{m}_{f} C_{f}} T_{a}+K_{k}{ }^{N} T_{f i}$

278 Where, the value of $T_{f i}$ is equal to $T_{w}$.

279 The temperature at the first collector's outlet will be the same as the temperature at the second 280 collector's inlet, the temperature at the second collector's outlet will be the same as the 281 temperature at the third collector's inlet, and so on. Using this condition, the fluid temperature at 282 the Nth collector's outlet can be calculated as follows:

$283 T_{f o N}=\frac{\left(A F_{R}(\alpha \tau)\right)_{1}}{\dot{m}_{f} C_{f}} \frac{\left(1-K_{k}^{N}\right)}{\left(1-K_{k}\right)} I(t)+\frac{\left(A F_{R} U_{L}\right)_{1}}{\dot{m}_{f} C_{f}} \frac{\left(1-K_{k}^{N}\right)}{\left(1-K_{k}\right)} T_{a}+K_{k}^{N} T_{f i}$

284 The heated fluid (water) available at the outlet of $\mathrm{N}^{\text {th }}$ collectors allowed to basin of SEBWP of

285 single slope type and hence, $T_{w o}=T_{f o N}$.After getting the fluid temperature at the outlet of Nth

286 collector, one can obtain the expression for useful heat gain as

287

$\dot{Q}_{u N}=\dot{m}_{f} C_{f}\left(T_{f o N}-T_{f i}\right)=\frac{\left(1-K_{k}^{N}\right)}{\left(1-K_{k}\right)}\left(A F_{R}(\alpha \tau)\right)_{1} I(t)+\frac{\left(1-K_{k}^{N}\right)}{\left(1-K_{k}\right)}\left(A F_{R} U_{L}\right)_{1}\left(T_{f i}-T_{a}\right)$

\subsection{For SEBWP of single slope type}

$289 \quad$ 5.2.1 For inside surface of condensing glass cover

$290 \quad \alpha_{g}^{\prime} I_{S}(t) A_{g}+h_{1 w}\left(T_{w}-T_{g i}\right) A_{b}=\frac{K_{g}}{L_{g}}\left(T_{g i}-T_{g o}\right) A_{g}$

291 Here, $\alpha_{g}^{\prime}=\left(1-R_{g}\right) \alpha_{g}$ denotes the effective absorptivity of glass cover and $h_{1 w}=h_{r w g}+$

$292 h_{c w g}+h_{e w g}$ represents the rate of net heat transfer coefficient between water surface and inner 293 surface of the glass cover.

294 Outer surface of condensing glass cover:

$295 \frac{K_{g}}{L_{g}}\left(T_{g i}-T_{g o}\right) A_{g}=h_{1 g}\left(T_{g o}-T_{a}\right) A_{g}$

296 Where, $h_{1 g}=h_{r g}+h_{c g}$ or $h_{1 g}=5.7+3.8 \mathrm{~V}$ 
$298 \dot{Q}_{u N}+\alpha_{w}^{\prime} I_{S}(t) A_{b}+h_{b w}\left(T_{b}-T_{w}\right) A_{b}=h_{1 w}\left(T_{w}-T_{g i}\right) A_{b}+M_{w} C_{w} \frac{d T_{w}}{d t}$

299 Where, $\alpha_{w}^{\prime}=\left(1-R_{g}\right)\left(1-\alpha_{g}\right)\left(1-R_{w}\right) \alpha_{w}$ which denotes the effective absorptivity of water 300 mass and $\dot{Q}_{u N}$ denotes useful heat gain per hour basis from N same evacuated tubular collectors 301 connected in series.

302 Basin liner:

$303 \quad \alpha_{b}^{\prime} I_{s}(t) A_{b}=h_{b w}\left(T_{b}-T_{w}\right) A_{b}+h_{b a}\left(T_{b}-T_{a}\right) \mathrm{A}_{\mathrm{b}}$

304 Where, $\alpha_{b}^{\prime}=\left(1-R_{g}\right)\left(1-\alpha_{g}\right)\left(1-R_{w}\right)\left(1-\alpha_{w}\right) \alpha_{b}=$ The fraction of solar flux absorbed by 305 basin liner.

306 Appendix-A contains the expressions for the different unknown terms used in equations (3) to 307 (6). The first order differential equation of water temperature $\left(T_{w}\right)$ for N-ETC-SS can be obtained 308 using equation (1) and equations (3) to (6)as mentioned:

$309 \frac{d T_{w}}{d t}+a_{1} T_{w}=f_{1}(t)$

310 Appendix-A contains the expressions for for $a_{1}$ and $f_{1}(t)$ used in equation (7). The solution

311 to differential equation (7) is written as

$312 \quad T_{w}=\frac{\overline{f_{1}}(t)}{a_{1}}\left(1-e^{-a_{1} t}\right)+T_{w 0} e^{-a_{1} t}$

313 Where, $T_{w 0}$ is the temperature of water at $t=0$ and during the time interval 0 - $\mathrm{t}$, the average

314 value of $f(t)$ can be expressed as $\bar{f}(t)$.After computing the value of $T_{w}$ with the help of equation 315 (8), one can evaluate values of glass temperature $\left(T_{g i}\right.$ and $\left.T_{g o}\right)$ using equations (3) and (4) as 316 follows.

$317 \quad T_{g i}=\frac{\alpha_{g}^{\prime} I_{s}(t) A_{g}+h_{1 w} T_{w} A_{b}+U_{c, g a} T_{a} A_{g}}{U_{c, g a} A_{g}+h_{1 w} A_{b}}$ 
$318 T_{g o}=\frac{\frac{K g}{L g} T g i+h_{1} T_{a}}{\frac{K g}{L g}+h_{1 g}}$

319 After estimating parameters namely water temperature $\left(T_{w}\right)$ and glass temperature, the hourly

320 yield $\left(\dot{m}_{e w}\right)$ can be estimated as:

$321 \quad \dot{m}_{e w}=\frac{h_{e w g} A_{b}\left(T_{w}-T_{g i}\right)}{L} \times 3600$

322 The value of $\mathrm{L}$ can be estimated using the relationship provided by Fernandez and Chargoy

323 (1990) and Toyama (1972).

\section{6. Analysis}

$325 \quad 6.1$ Statistical analysis

326 The rapport between values based on theoretical as well as experimental analyses of different 327 parameters $\left(T_{w}, T_{g}\right.$ and potable water production) can be determined by calculating the coefficient 328 of correlation $\left(r_{1}\right)$ and the root mean square percent deviation (e). The value of KARL 329 PEARSON'S coefficient of correlation $\left(\mathrm{r}_{1}\right)$ can be estimated as:

$330 \quad r_{1}=\frac{\sum\left(x_{i}-\bar{x}\right)\left(y_{i}-\bar{y}\right)}{\sqrt{\sum\left(x_{i}-\bar{x}\right)^{2} \sum\left(y_{i}-\bar{y}\right)^{2}}}$

331 The value of e can be estimated as:

$332 e=\sqrt{\frac{\sum\left[\frac{\left(x_{i}-y_{i}\right)}{x_{i}}\right]^{2}}{N_{0}}}$

333 The coefficient of determination can be evaluated as the square of correlation coefficient $\left(r_{1}^{2}\right)$. It

334 measures how well the model replicates experiential values (Chapra and Canale 1989, Nakara 335 Chaudhary 2004). Furthermore, the experiment's internal uncertainty has been estimated. 
336 Measurement uncertainty is influenced by both fixed and random errors. The value of standard

337 uncertainty can be computed as (Bell 1999):

$338 \quad U_{I}=\sqrt{\sum_{t=1}^{N_{s}} \sqrt{\frac{\sigma_{t}^{2}}{N_{o}-1}}}$

339 Here, $\sigma$ denotes the standard deviation and it can be computed as

$340 \sigma=\sum_{t=1}^{N_{o}}\left(X_{t}-\bar{X}\right)^{2}$

$341 N_{S}$ denotes the number of sets and $N_{o}$ denotes the total number of observations. The value of

342 percentage uncertainty can be computed as

343 Percentage uncertainity $=\frac{U_{I}}{\text { Average of total number of observations }} \times 100$

$344 \quad 6.2$ Uniform end of year annual cost (UEOYAC), cost of potable water (COPW) and 345 productivity analyses:

\section{$346 \quad$ 6.2.1 UEOYAC analysis}

347 The value of UEOYAC for SEBWP of single slope type integrated with $\mathrm{N}$ alike ETCs can be 348 estimated as (Tiwari 2002):

$349 \quad U E O Y A C=\mathrm{PC} \times \mathrm{CRF}+\mathrm{MC} \times \mathrm{CRF}-\mathrm{SV} \times \mathrm{SFF}$

350 Where PC, SV, CRF, SFF and MC stand for present cost, salvage value, capital recovery factor, 351 sinking fund factor and maintenance cost in that order. The value of MC may be estimated as the 352 multiplication of PC with maintenance cost factor that is normally considered as 0.1 . The value 353 of CRF which is used for converting PC into UEOYAC and can be expressed as: 
$354 \quad \mathrm{CRF}=\frac{i \times(1+i)^{n}}{(1+i)^{n}-1}$

355 and SFF can be written as

$356 \quad \mathrm{SFF}=\frac{i}{(1+i)^{n}-1}$

357 SFF is applied for converting SV into UEOYAC. In this case, $\mathrm{i}$ and $\mathrm{n}$ stand for the rate of interest 358 and system life, respectively.

359 The value of PC for a SEBWP of single slope type integrated with ETCs with a 30-year life span 360 can be calculated as

$361 \quad \mathrm{PC}=P I+P_{\mathrm{u}}+\frac{P_{u}}{(1+i)^{10}}+\frac{P_{\mathrm{u}}}{(1+i)^{20}}$

362 Where, $\mathrm{PI}=$ Cost of solar still + Cost of ETCs+ Fabrication cost

363 The cost of fabrication also involves piping and labor. Values of UEOYAC have been evaluated 364 using equation (20) and they have been presented in Table 5. The required capital investment has 365 been presented as Table 4.

$366 \quad$ 6.2.2 COPW analysis

367 The cost of obtaining per $\mathrm{kg}$ of fresh water from SEBWP of single slope type integrated with 368 ETCs can be written as

$369 \quad C O P W=\frac{U E O Y A C}{\text { Annual yield }}$

370 Values of COPW have been estimated using equation (25) and they have been presented in Table 3715.

$372 \quad$ 6.2.3 Productivity analysis

373 Productivity gives the relation between output and input and it is different from efficiency in the 374 sense that the value of productivity should always be more than $100 \%$ whereas the value of 
375 efficiency should be less than $100 \%$. Higher the pruductivity better will be the living standard of

376 persons because higher productivity means more products are available for use. It is also

377 expressed as the rtio of effectiveness and efficiency. The value of annual productivity for

378 SEBWPof single slope type integrated with ETCs can be estimated as (Ashcroft 1950, Benson

379 1952, Cox 1951, International Labor Office 1979):

380

Productivity $=\frac{\text { output from SEBWP integrated wit ETCS }}{\text { Input provided toSEBWP integrated wit ETCS }} \times 100$

381 Here, output from SEBWPof single slope type integrated with ETCs represents the annual fresh 382 water produced from the system. This output can be expresse in terms of rupees by multiplying 383 the amount of annual fresh water in $\mathrm{kg}$ with unit cost (Rs./kg) of fresh water sold in the market. 384 Hence, output from SEBWP of single slope type integrated with ETCs in terms of Rs. can be 385 written as

Output from SEBWP integrated with ETCs $=($ Annual yield $) \times($ Selling price $)$

387 Input provided to SEBWPof single slope type integrated with ETCs will be UEOYAC and it can 388 be estimated using equation (20). The productivity has been evaluated using equation (26) and 389 has been presnted in Table 5.

\subsection{Energy metrics analysis}

391 The energy metrics analysis is an essential part of solar energy technology because the 392 application of solar energy technology is not justifiable if energy produced by solar energy based 393 system during the entire life span is less than the value of embodied energy of the solar system. It 394 involve the calculation of energy payback time $\left(T_{E P B}\right)$, life cycle conversion efficiency $\left(\eta_{L C C}\right) \&$ 395 energy production factor $\left(F_{E P}\right)$. Energy metrics offers the performance of the system over a 
396 longer period of time. The embodied energy encompasses both energy as well exergy; however,

397 the exergy part is much higher than the energy part. Embodied energy is one of the most

398 important parameters for the calculation of $T_{E P B}$. Economics of renewable energy system

399 involves the selection of low embodied energy for the selected system. It is essential to focus on

400 the energy densities of all the materials involves in the fabrication of the renewable energy

401 assisted system to calculate the total embodied energy. Embodied energy of the different

402 components has been determined by the product of mass of the component with the energy

403 density of that material. Total embodied energy is calculated by sum of embodied energy for

404 individual components.

405

\subsection{1 $T_{E P B}$ analysis}

406 The term $T_{E P B}$ for SEBWPof single slope type integrated with ETCs is the time span required to 407 recover embodied energy which is known as the energy needed for the production of SEBWP of 408 single slope type integrated with ETCs. The value of $T_{E P B}$ can be calculated taking energy or 409 exergy as the basis; however, the value of $T_{E P B}$ on the basis of energy is far lower than the 410 exergy based $T_{E P B}$ because exergy means quality of energy and the amount of exergy produced 411 by the system is much lower than the energy obtained from the system. A comparatively poorer 412 value of $T_{E P B}$ is expected as lower value of $T_{E P B}$ means the energy or exergy based breakeven 413 point will be obtained in lesser time and higher amount of energy will be produced which results 414 in higher amount of carbon credit. $T_{E P B}$ for SEBWP of single slope type integrated with ETCs on 415 the basis of energy as well as exergy can be expressed as: 
$417 \quad T_{E P B, \text { exergy }}=\frac{\text { Embodiedenergy of } S E B W P \text { integrated with } E T C S\left(E_{\text {in }}\right)}{\text { Annualexergyoutput obtained from SEBWP integrated with ETCS }\left(E_{\text {out }}\right)}$

418 The value of hourly exergy rate can be estimated as follows:

419 Hourly exgy $=h_{\text {ewg }} \times A \times\left[\left(T_{w}-T_{g i}\right)+\left(T_{a}+273\right) \ln \left\{\frac{\left(T_{w}+273\right)}{\left(T_{g i}+273\right)}\right\}\right]$

\subsection{2 $F_{E P}$ analysis}

421 The term $\boldsymbol{F}_{\boldsymbol{E P}}$ for SEBWPof single slope type integrated with ETCs is defined as the ratio of

422 Annual energy output obtained from SEBWP of single slope type integrated with ETCs to 423 energy needed for the production of SEBWP of single slope type integrated with ETCs. Thus,

$424 F_{E P}$ is the reciprocal of term $T_{E P B}$ that represents the overall performance of the system. The 425 ideal value on annual basis is 1. Values of $E P F F_{E P}$ for EBWP integrated with ETCs on the basis 426 of energy as well as exergy can be estimated as:

$427 \quad \boldsymbol{F}_{E P, \text { energy }}=\frac{\text { Annualenergyoutput obtained from SEBWP integrated with ETCS }\left(E_{\text {out }}\right)}{\text { Embodiedenergy of SEBWP integrated with ETCS }\left(E_{\text {in }}\right)}$

$\boldsymbol{F}_{\boldsymbol{E}, \text { exergy }}=\frac{\text { Annualenergyoutput obtained from SEBWP integrated with ETCS }\left(E_{\text {out }}\right)}{\text { Embodiedexergy of } S E B W P \text { integrated with } E T C S\left(E_{\text {in }}\right)}$

\section{$429 \quad 6.3 .3 \quad \eta_{L C C}$ analysis}

430 The term $\eta_{L C C}$ gives an idea about net output of SEBWP of single slope type integrated with

431 ETCs with regard to solar energy impinging the surface of the system for the whole life span of 432 the system. The ideal value of LCCE for SEBWP of single slope type integrated with ETCs is 433 one. The system is considered performing better in the value of $\eta_{L C C}$ is higher. Value of $\eta_{L C C}$ for 434 SEBWP of single slope type integrated with ETCs on the basis of energy and exergy can be 435 estimated as 
$436 \quad \eta_{L C C, \text { exergy }}=\frac{(\text { Annual energy } \times n)-E_{\text {in }}}{(\text { Annual solar exergy }) \times n}$

$437 \quad \eta_{L C C, \text { exergy }}=\frac{(\text { Annual exergy } \times n)-E_{\text {in }}}{(\text { Annual solar exergy }) \times n}$

438 The variation of monthly solar energy falling on the surface of system has been presented in Fig.

439 6. By adding monthly exergy for twelve months, value annual solar energy impinging on the

440 surface can be estimated. Values of $\eta_{L C C}$, have been estimated using equations (32) and (33) and

441 they have been presented in Table 6.

442 6.4 Exergoeconimic and enviroeconomic analyses of SEBWP of single slope type integrated

443 with ETCs:

444 6.4.1Exergoeconimic analysis of SEBWP of single slope type integrated with ETCs:

445 The value of exergoeconomic parameter has been estimated using first and second laws of 446 thermodynamics. This relationship means that the system is constructed in such a way that it 447 achieves an overall optimum design by efficiently balancing the exergy and economic 448 parameters. The exergoeconimic parameter relates either exergy loss or exergy gain with 449 UEOYAC. In the case of exergy gain, the objective is maximization type, whereas, in the case of 450 exergy loss, the objective is minimization type. The parameter exergoeconomic can be estimated 451 as:

452 Exergoeconomic parameter $=\frac{\text { Annual exergy loss for SEBWP integarted with ETCs }\left(L_{\text {ex }, \text { annual })}\right.}{U E O Y A C}$

453 Here, rate of exergy loss for SEBWP can be estimated as 
$454 \quad L_{\text {ex,annual }}=\left[\left(h_{c w c}+h_{r w c}\right)\left\{\left(T_{w}-T_{g i}\right)+\left(T_{a}+273\right) \ln \left\{\frac{\left(T_{w}+273\right)}{\left(T_{g i}+273\right)}\right\}\right)\right]+\left[\left(M_{w} C_{w}\right)\left\{\left(T_{w f}-\right.\right.\right.$

$\left.\left.\left.455 \quad T_{w i}\right)+\left(T_{a}+273\right) \ln \left\{\frac{\left(T_{w f}+273\right)}{\left(T_{w i}+273\right)}\right\}\right\}\right]$

456 Here, $h_{c w c}$ and $h_{r w c}$ represent convective and radiative heat transfer coefficients from water

457 surface to inside surface of condensing cover. $M_{w}$ stands for mass of water in basin, $T_{w f}$ is the

458 final temperature of water and $T_{w i}$ is the initial temperature of water.

459 6.4.2 Enviroeconomic analysis of SEBWP of single slope type integrated with ETCs:

460 It provides economic incentive for controlling environmental pollution so that the emission of 461 pollutants can be reduced and motivates individual to apply renewable energy technology which 462 does not affects the environment. It can be estimated as:

Enviroeconmic parameter $=(($ Annual energy out $) \times n-$ Embodied energy $)(0.002)(\mathrm{CRP})$

\section{Results and discussion}

466 The data for one year from August 2018 to July 2019 was noted after installation of SEBWP of 467 single slope type integrated with ETCs. These values of all relevant equations have been made 468 input to programming code written in MATLAB. This MATLAB code has been used to estimate 469 the values of water temperature, glass temperature and yield. These values have been plotted as 470 shown in Fig. 3 and values of $r$ and e were estimated using equations (15) and (16) respectively.

471 The various performance parameters based on the output of MATLAB code have presented in 472 Figs. 2-5 and Table 4 to Table 8. 


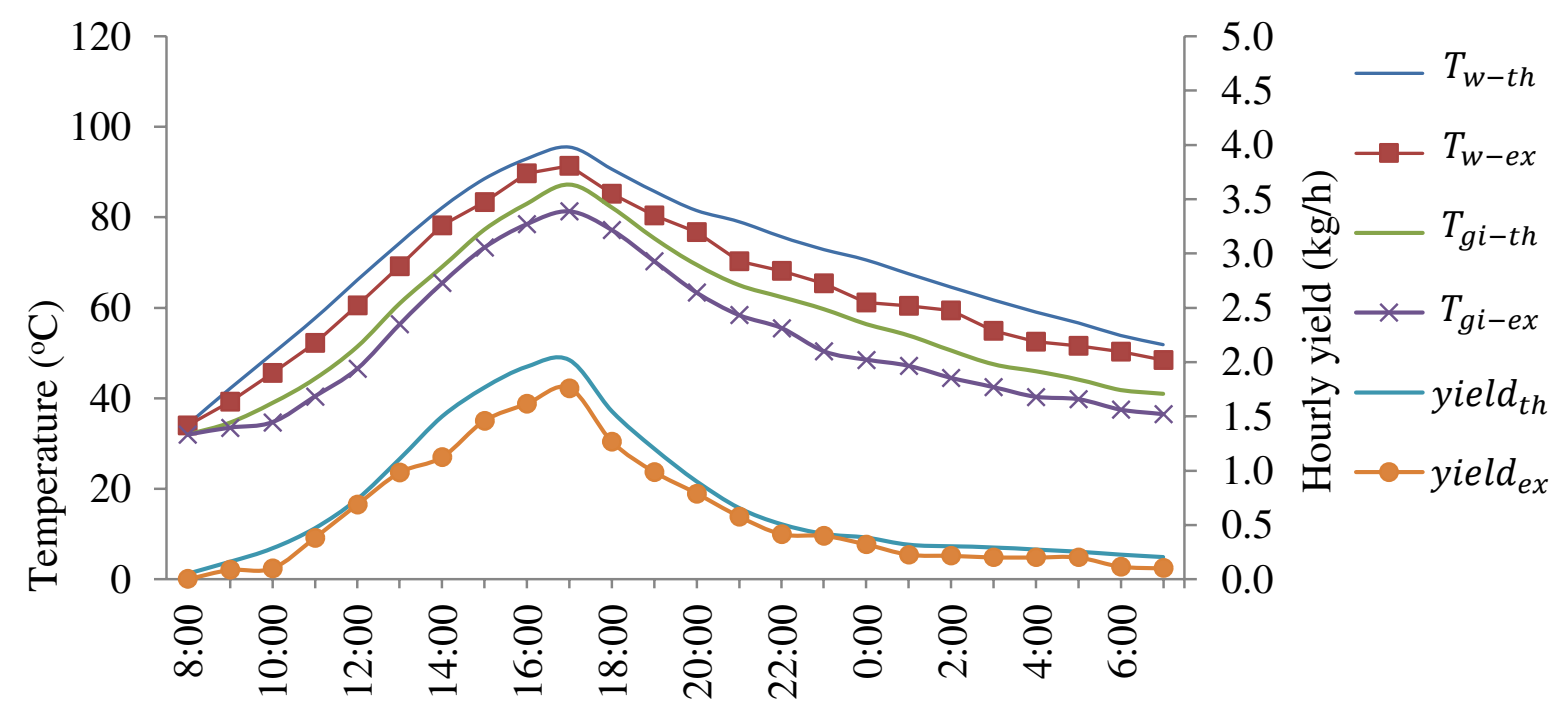

Time (h)

473

474 475

476

477 478

\begin{tabular}{lccr}
\hline Typical day of month & $\begin{array}{c}\text { Number of clear days } \\
(\mathbf{d a y})\end{array}$ & $\begin{array}{c}\text { Daily yield } \\
(\mathbf{K g})\end{array}$ & $\begin{array}{r}\text { Monthly yield } \\
(\mathbf{K g})\end{array}$ \\
\hline $02-08-18$ & 18 & 8.95 & 161.14 \\
$28-09-18$ & 19 & 8.90 & 169.19 \\
$11-10-18$ & 27 & 9.70 & 261.98 \\
$07-11-18$ & 24 & 3.54 & 84.94 \\
$16-12-18$ & 29 & 1.79 & 51.92 \\
$03-01-19$ & 17 & 2.40 & 40.80 \\
$03-02-19$ & 13 & 3.15 & 40.91 \\
$19-03-19$ & 29 & 5.53 & 160.37 \\
$29-04-19$ & 28 & 14.20 & 397.71 \\
$19-05-19$ & 30 & 10.16 & 304.89 \\
$08-06-19$ & 24 & 11.15 & 267.55 \\
$02-07-19$ & 16 & 10.07 & 161.12 \\
\hline Annual yield $\mathbf{( K g )}$ & & & $\mathbf{2 1 0 2 . 5 3}$ \\
\hline
\end{tabular}

Fig. 2: Validation of values of $T_{w}, T_{g i}$ and hourly yield on April 29, 2019 for SEBWP of single slope type integrated with evacuated tubular collectors

Table 3: Calculation for annual production of potable water for SEBWP of single slope type integrated with evacuated tubular collectors 
480 Fig. 2 represents the validation of values of $T_{w}, T_{g i}$ and hourly yield on April 29, 2019 for

481 SEBWP of single slope type integrated with ETCs. Values of $\mathrm{r}$ and e for $T_{w}, T_{g i}$ and hourly yield 482 have been estimated using equations (15) and (16) respectively. It has been found that values of $r$ 483 varies from 0.9928 to 0.9951 and that of e varies from $8.2 \%$ to $28.53 \%$ which show that there is 484 a fair agreement between theoretically calculated vales and experimentally collected values for $485 T_{w}, T_{g i}$ and hourly yield. Table 3 represents the evaluation of annual yield for SEBWP of single 486 slope type integrated with ETCs based on experimentally collected values for typical day of each 487 month.

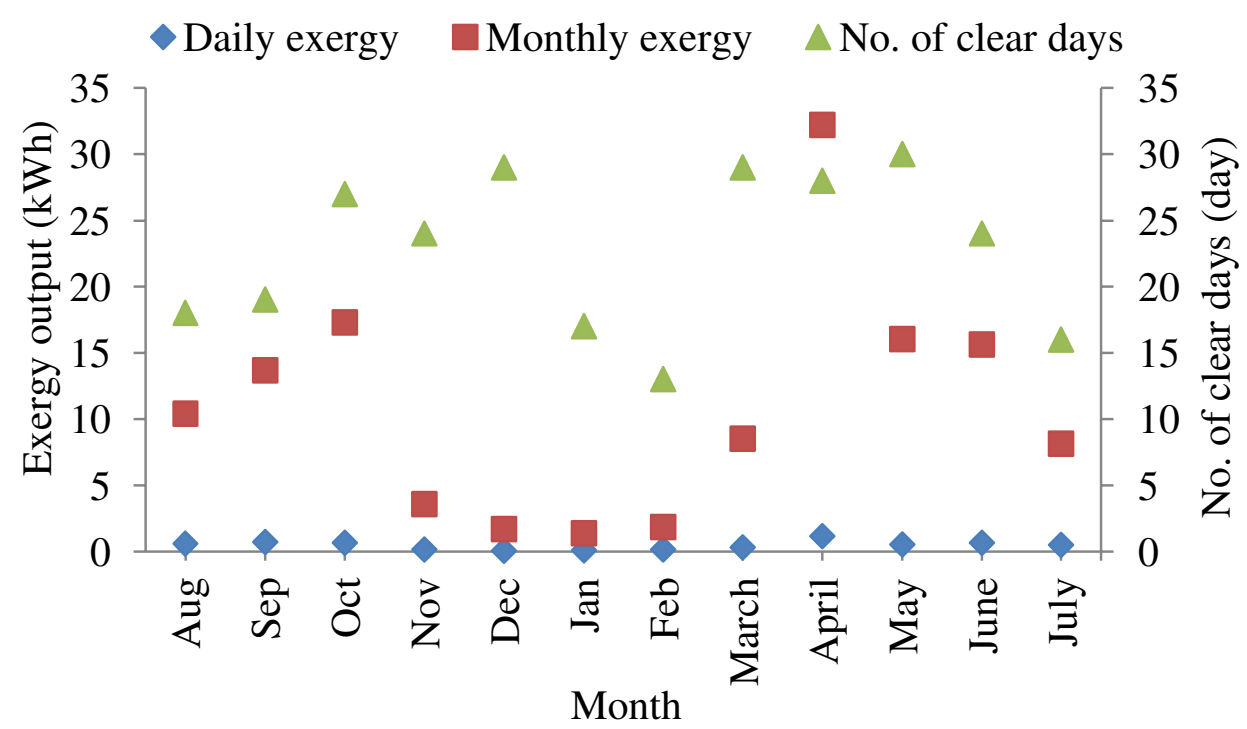

Fig. 3: Variation of monthly exergy output for SEBWP of single slope type integrated with evacuated tubular collectors

Fig. 3 represents the variation of monthly exergy output for SEBWP of single slope type integrated with evacuated tubular collectors. The hourly exergy output has been estimated using equation (30) followed by the estimation of daily exergy by summing hourly exergy for $24 \mathrm{~h}$. The monthly exergy has been estimated by multiplying daily exergy with number of clear days in that month. It has been found that monthly exergy is maximum for April because of better 
496 solar intensity received in the month of April. Further, the value of monthly exergy depends on

497 daily exergy and number of clear days.

498 Table 4: Capital investment for SEBWP of single slope type integrated with evacuated tubular collectors

\begin{tabular}{llc}
\hline S.N. & Parameter & cost \\
\hline 1 & Solar still & 12000 \\
2 & Copper tube @ 280 per meter & 14924 \\
3 & Evacuated tube @ 500each & 6500 \\
4 & Aluminum stand & 3000 \\
5 & Iron stand for solar still & 1000 \\
6 & Motor and pump & 2000 \\
7 & Fabrication cost & 5000 \\
8 & Salvage value of the system after 30 years taking inflation rate is 4\% & 13755.46 \\
\hline
\end{tabular}

501 Table 5: Calculation of UEOYAC production cost and productivity for SEBWP of single slope 502 type integrated with evacuated tubular collectors

\begin{tabular}{ccccccccc}
\hline \multicolumn{8}{c}{ Evaluation of UEOYAC } \\
\hline S.N. & $\mathrm{n}$ & $\mathrm{i}$ & $\mathrm{PC}$ & $\mathrm{M}$ & $\mathrm{SV}$ & $\mathrm{F}_{\mathrm{CR}, \mathrm{i}, \mathrm{n}}$ & $\mathrm{F}_{\mathrm{SR}, \mathrm{i}, \mathrm{n}}$ & UEOYAC \\
& $($ Year $)$ & $(\%)$ & Rs. & Rs. & Rs. & (Fraction) & (Fraction) & Rs. \\
\hline 1 & 30 & 2 & 47410.64 & 4741.06 & 13755.46 & 0.045 & 0.025 & 2002.94 \\
2 & 30 & 5 & 46405.61 & 4640.56 & 13755.46 & 0.065 & 0.015 & 3111.67 \\
3 & 30 & 10 & 45492.37 & 4549.24 & 13755.46 & 0.106 & 0.006 & 5221.88 \\
\hline \multicolumn{7}{c}{ Evaluation of COPW and Productivity } \\
\hline S.N. & $\mathrm{n}$ & $\mathrm{i}$ & UEOYAC & AY & COPW & SP & RE & Productivity \\
& $($ Year) & $(\%)$ & Rs. & (kg) & (Rs./kg) & Rs. & Rs. & $(\%)$ \\
\hline 1 & 30 & 2 & 2002.94 & 2102.53 & 0.95 & 5 & 10512.65 & 524.86 \\
2 & 30 & 5 & 3111.67 & 2102.53 & 1.48 & 5 & 10512.65 & 337.85 \\
3 & 30 & 10 & 5221.88 & 2102.53 & 2.48 & 5 & 10512.65 & 201.32 \\
\hline
\end{tabular}

504 The investment in installing SEBWP of single slope type integrated with ETCs has been 505 presented in Table 4. The cost of different components is the price of products as per local 506 market. Also, the salvage value has been estimated as per the local market price. UEOYAC for 507 SEBWP of single slope type has been estimated using equation (20) and they have been 
presented in Table 5. The life span of SEBWP integrated with ETCs has been taken as 30 years except motor and pump. The life of pump with motor has been taken as 10 years and it has been assumed that the inflation after 10 years can be adjusted with its salvage value. The rate of interest has been considered as $2 \%, 5 \%$ and $10 \%$. The value of UEOYAC is minimum for $2 \%$ rate of interest as $2 \%$ rate of interest is minimum. Values of COPW and annual productivity for SEBWP of single slope type integrated with ETCs has been estimated using equations (25) and 26 respectively and they have been presented in Table 5. It is found that the value of COPW is minimum for $2 \%$ rate of interest because UEOYAC is minimum for $2 \%$ rate of interest. Further, the value of productivity is maximum for $2 \%$ rate of interest as UEOYAC value is minimum for $2 \%$ rate of interest. Also, productivity is inversely proportional to UEOYAC as evident from equation (26). It has also been observed that the value of productivity is more than $100 \%$ for all interest rates under consideration. It means that the system is feasible.

Table 6 presents the calculation of embodied energy $\left(E_{i n}\right)$, energy payback time $\left(T_{E P B}\right)$, energy production factor $\left(F_{E P}\right)$ and $\eta_{L C C}$ for SEBWP of single slope type integrated with ETCs. Fig. 4 presents the variation of monthly solar energy falling on the surface of SEBWP of single slope type integrated with ETCs. The value of embodied energy has been estimated as the product of energy density $(\mathrm{kWh} / \mathrm{kg})$ and mass $(\mathrm{kg})$. The mass of different components has been calculated as the product of density $\left(\mathrm{kg} / \mathrm{m}^{3}\right)$ and volume $\left(\mathrm{m}^{3}\right)$. Values of $T_{E P B \text {,energy }}$ and $T_{E P B \text {,exergy }}$ has been found to be 1.72 year and 25.9 year respectively. The value of $T_{E P B \text {,energy }}$ is lower than $T_{E P B, \text { exergy }}$ because exergy represents the quality of energy (high grade energy) and hence lower value of exergy is obtained from SEBWP of single slope type integrated with ETCs. Values of $F_{E P, \text { energy }}$ and $F_{E P, \text { exergy }}$ have been found to be 0.58 and 0.039 . The value of $F_{E P, \text { energy }}$ is higher as $F_{E P}$ is the reciprocal of $T_{E P B}$ as evident from equations (31) to (34). Values of 
$\eta_{L C C, \text { energy }}$ is higher than $\eta_{L C C \text {,exergy }}$ because exergy is lower than energy as exergy represents

532 the quality of energy.

533

534 Table 6: Calculation of embodied energy $\left(E_{i n}\right)$, energy payback time $\left(T_{E P B}\right)$, energy production

535 536 factor $\left(F_{E P}\right)$ and life cycle conversion efficiency $\left(\boldsymbol{\eta}_{\boldsymbol{L} C \boldsymbol{C}}\right)$ for SEBWP of single slope type integrated with evacuated tubular collectors

\begin{tabular}{|c|c|}
\hline \multirow[t]{2}{*}{ Name of component } & $\begin{array}{l}\text { Solar energy based water purifier of single slope type integrated } \\
\text { with ETCs }\end{array}$ \\
\hline & Embodied energy (kWh) \\
\hline $\begin{array}{l}\text { Solar still } \\
\text { ETC (N=13) } \\
\text { Others }\end{array}$ & $\begin{array}{c}706.99 \\
1287.43 \\
20\end{array}$ \\
\hline \multicolumn{2}{|c|}{ Single slope PVT-FPC active solar distillation system } \\
\hline \multicolumn{2}{|l|}{ Annual yield $=2102.53 \mathrm{~kg}$} \\
\hline \multicolumn{2}{|c|}{ Net annual energy available from SEBWP of single slope type integrated with ETCs $=1170.95 \mathrm{kWh}$} \\
\hline \multicolumn{2}{|c|}{ Net annual exergy available from SEBWP of single slope type integrated with ETCs $=77.76 \mathrm{kWh}$} \\
\hline \multicolumn{2}{|l|}{ Life of the system $($ Year $)=30$} \\
\hline \multicolumn{2}{|c|}{ The value of $T_{E P B}$ for SEBWP of single slope type integrated with ETCs based on energy (year) $=1.72$} \\
\hline \multicolumn{2}{|c|}{ The value of $T_{E P B}$ for SEBWP of single slope type integrated with ETCs based on exergy (year) $=25.90$} \\
\hline \multicolumn{2}{|c|}{ The value of $F_{E P}$ for SEBWP of single slope type integrated with ETCs based on energy (per year $)=0.58$} \\
\hline \multicolumn{2}{|c|}{ The value of $F_{E P}$ for SEBWP of single slope type integrated with ETCs based on exergy (per year $)=0.039$} \\
\hline \multicolumn{2}{|c|}{ Solar energy for life time $\left(E_{\text {sol }}\right)$ in $k W h=144770.23$} \\
\hline \multicolumn{2}{|c|}{ Solar exergy for life time $\left(E_{\text {sol }}\right)$ in $k W h=134636.31$} \\
\hline \multicolumn{2}{|c|}{ The value of $\boldsymbol{\eta}_{\boldsymbol{L} C \boldsymbol{C}}$ for SEBWP of single slope type integrated with ETCs based on energy (fraction) $=0.23$} \\
\hline The value of $\boldsymbol{\eta}_{\boldsymbol{L} C \boldsymbol{C}}$ for SEBWP & slope type integrated with ETCs based on exergy (fraction) $=0.0024$ \\
\hline
\end{tabular}


Daily solar energy $\triangle$ Monthly solar energy $\square$ No. of clear days

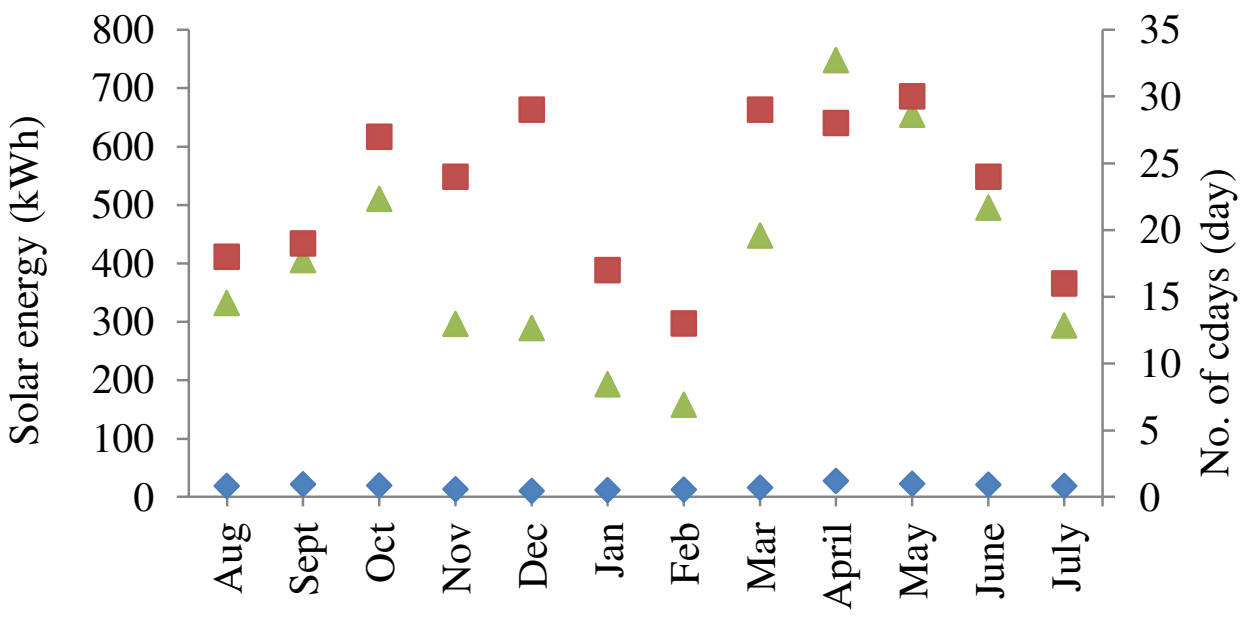

Month

540 Fig. 4: Variation of monthly solar energy falling on the surface of SEBWP of single slope type integrated with evacuated tubular collectors

542 Table 7: Evaluation of exergoeconomic parameter for SEBWP of single slope type integrated 543 with evacuated tubular collectors

\begin{tabular}{rrrrcc}
\hline S.N. & $\begin{array}{c}\text { n } \\
(\text { Year })\end{array}$ & $\begin{array}{c}\text { i } \\
(\boldsymbol{\%})\end{array}$ & $\begin{array}{c}\text { UEOYAC } \\
(\text { Rs. })\end{array}$ & $\begin{array}{c}\text { Annual Exergy loss } \\
(\mathbf{k W h})\end{array}$ & $\begin{array}{c}\text { Exergoeconomic parameter } \\
(\mathbf{k W h} / \mathbf{R s .})\end{array}$ \\
\hline 1 & 30 & 2 & 2002.94 & 669.1278 & 0.334 \\
2 & 30 & 5 & 3111.669 & 669.1278 & 0.215 \\
3 & 30 & 10 & 5221.878 & 669.1278 & 0.1281 \\
\hline
\end{tabular}

544

545

Table 8: Evaluation of enviroeconomic parameter for SEBWP of single slope type integrated with evacuated tubular collectors

Single slope active solar still

Life (year)

Embodied energy (kWh)

Net annual energy available $(\mathrm{kWh})$

Net energy available (kWh) for life time

$\mathrm{CO}_{2}$ credit ( $\left.\mathrm{t}\right)$

Environmental cost (Enviroeconomic parameter) (\$)
2014.42

1170.95

35128.50

66.22

960.31 
548 Table 7 presents the estimation of exergoeconomic parameter for SEBWP of single slope type 549 integrated with ETCs and Fig. 5 presents the variation of monthly exergy loss for SEBWP of 550 single slope type integrated with ETCs. The value of exergoeconomic parameter has been found 551 to be minimum for $10 \%$ rate of interest because UEOYAC is highest for this interest rate. Table 5528 presents the evaluation of enviroeconomic parameter for SEBWP of single slope type 553 integrated with ETCs. The carbon credit has been estimated as $66.22 \mathrm{t}$ and the corresponding 554 enviroeconimic parameter has been found to be $960.31 \$$.

555

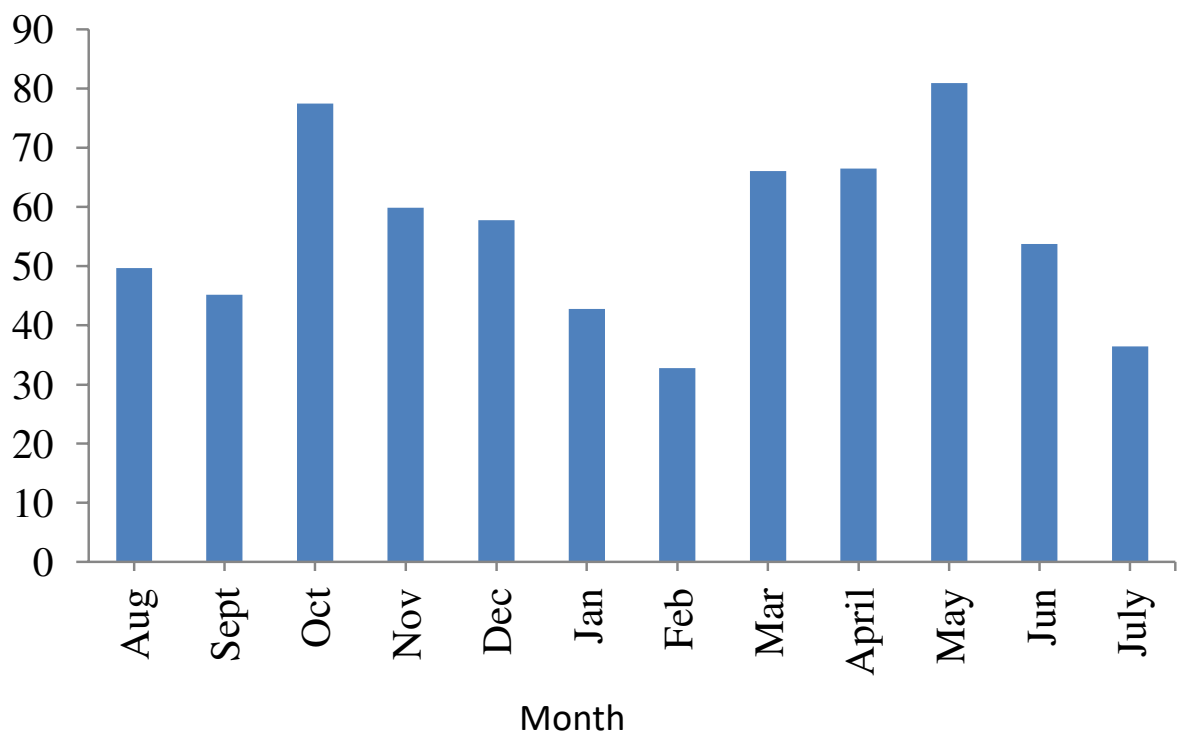

Fig. 5: Variation of monthly exergy loss for SEBWP of single slope type integrated with evacuated tubular collectors

\section{Conclusions}

The experimental study of SEBWP of single slope type integrated with ETCs has been carried out and based on the findings of this research; the following conclusions have been drawn:

i. A fair agreement has been found between experimental and theoretical values of $\mathrm{T}_{\mathrm{w}}$, $\mathrm{T}_{\mathrm{gi}}$ and yield with correlation coefficient varying between 0.9928 and 0.9951 . 
ii. COPW values have been found to range from Rs. 0.95 to Rs. 2.48 as interest rates range from $2 \%$ to $10 \%$.Values of productivity have been found to be more than $100 \%$ which represent that the system is feasible.

iii. Values of $T_{E P B \text {,energy }}$ and $T_{E P B \text {,exergy }}$ have been found to be 1.72 years and 25.90 years respectively; values of $F_{E P \text {,energy }}$ and $F_{E P, \text { exergy }}$ have been found to be 0.58 per year and 0.039 per year respectively; whereas, values of $\boldsymbol{\eta}_{\boldsymbol{L} \boldsymbol{C} \boldsymbol{C} \text {, energy }}$ and $\boldsymbol{\eta}_{\boldsymbol{L} C \boldsymbol{C}, \boldsymbol{e x e r g y}}$ have been found to be 0.23 and 0.0024 respectively. between 0.13 and 0.33 .

\section{Appendix}

574

$\left(A F_{R}(\alpha \tau)\right)_{1}=P F_{1} \alpha \tau^{2} A_{R} F_{R} ; \quad\left(A F_{R} U_{L}\right)_{1}=\left(1-K_{k}\right) \dot{\mathrm{m}}_{\mathrm{f}} \mathrm{c}_{\mathrm{f}} ;$

$575 \quad P F_{1}=\frac{h_{p f}}{F^{\prime} h_{p f}+U_{t p a}} ; \quad U_{L}=\frac{U_{t, p a} \cdot h_{p f}}{F^{\prime} h_{p f}+U_{t, p a}}$;

$576 \quad F_{R}=\frac{\dot{m}_{f} C_{f}}{U_{L} A_{R}}\left[1-\exp \left(-\frac{2 \pi \mathrm{r}^{\prime} \mathrm{L}^{\prime} \mathrm{U}_{\mathrm{L}}}{\dot{\mathrm{m}}_{\mathrm{f}} \mathrm{c}_{\mathrm{f}}}\right)\right] ;$

$577 \quad K_{K}=\left(1-\frac{A_{R} F_{R} U_{L}}{\dot{m}_{f} c_{f}}\right)$

$578 h_{p f}=100 \mathrm{Wm}^{2} \mathrm{~K}^{-1}$

$579 U_{t, p a}=\left[\frac{R o_{2}}{R_{O 1} h_{i}}+\frac{R_{o 2} \ln \left(\frac{R i_{2}}{R i_{1}}\right)}{K_{g}}+\frac{1}{C_{e v}}+\frac{R_{o 2} \ln \left(\frac{R o_{2}}{R o_{1}}\right)}{K_{g}}+\frac{1}{h_{o}}\right]^{-1}$

$580 \quad a_{1}=\frac{1}{M_{w} C_{w}}\left[\dot{m}_{f} C_{f}\left(1-K_{k}^{N}\right)+U_{s} A_{b}\right] ;$

$581 \quad \bar{f}_{1}(t)=\frac{1}{M_{w} C_{w}}\left[\alpha_{e f f}^{\prime} A_{b} \bar{I}_{s}(t)+\frac{\left(1-K_{k}^{N}\right)}{\left(1-K_{k}\right)}\left(A F_{R}(\alpha \tau)\right)_{1} \bar{I}_{c}(t)+\left(\frac{\left(1-K_{k}^{N}\right)}{\left(1-K_{k}\right)}\left(A F_{R} U_{L}\right)_{1}+U_{s} A_{b}\right) \bar{T}_{a}\right]$;

$$
\alpha_{e f f}^{\prime}=\alpha_{w}^{\prime}+h_{1} \alpha_{b}^{\prime}+h_{1}^{\prime} \alpha_{g}^{\prime} ; h_{1}=\frac{h_{b w}}{h_{b w}+h_{b a}}
$$


$h_{1}^{\prime}=\frac{h_{1 w} A_{g}}{U_{c, g a} A_{g}+h_{1 w} A_{b}} ; h_{1 w}=h_{r w g}+h_{c w g}+h_{e w g} ;$

$584 \quad h_{e w g}=16.273 \times 10^{-3} h_{c w g}\left[\frac{P_{w}-P_{g i}}{T_{w}-T_{g i}}\right] ;$

$585 h_{c w g}=0.884\left[\left(T_{w}-T_{g i}\right)+\frac{\left(P_{w}-P_{g i}\right)\left(T_{w}+273\right)}{268.9 \times 10^{3}-P_{w}}\right]^{\frac{1}{3}} ;$

$586 P_{w}=\exp \left[25.317-\frac{5144}{T_{w}+273}\right] ; P_{g i}=\exp \left[25.317-\frac{5144}{T_{g i}+273}\right] ;$

$587 h_{r w g}=\left(0.82 \times 5.67 \times 10^{-8}\right)\left[\left(T_{w}+273\right)^{2}+\left(T_{g i}+273\right)^{2}\right]\left[T_{w}+T_{g i}+546\right] ;$

$588 \quad U_{s}=U_{t}+U_{b} ; U_{b}=\frac{h_{b a} h_{b w}}{h_{b w}+h_{b a}} ; U_{t}=\frac{h_{1 w} U_{c, g a} A_{g}}{U_{c, g a} A_{g}+h_{1 w} A_{b}} ;$

$589 U_{c, g a}=\frac{\frac{K g}{l_{g}} h_{1 g}}{\frac{K g}{l_{g}}+h_{1 g}} ; h_{b a}=\left[\frac{L_{i}}{K_{i}}+\frac{1}{h_{c b}+h_{r b}}\right]^{-1}$;

$593 \quad$ Nomenclatures

594 SEBWP solar energy based water purifier

595 ETCs evacuated tubular collectors

$596 \mathrm{~N}$ number of evacuated tubular collectors

597 GI galvanized iron

$598 \quad \mathrm{I}(\mathrm{t}) \quad$ solar intensity falling on the surface of collector, $\mathrm{W} / \mathrm{m}^{2}$

$599 \mathrm{I}_{\mathrm{S}}(\mathrm{t}) \quad$ solar intensity falling on the surface of SEBWP, W/m $/ \mathrm{m}^{2}$

$600 \mathrm{R} \quad$ outer radius of glass tube, $\mathrm{m}$

$601 \quad F^{\prime} \quad$ collector efficiency factor, fraction

$602 \quad h_{p f} \quad$ heat transfer coefficient from plate to fluid, $\mathrm{W} / \mathrm{m}^{2}-\mathrm{K}$

$603 T_{p} \quad$ temperature of absorber plate, ${ }^{\circ} \mathrm{C}$

$604 T_{f} \quad$ temperature of fluid/water, ${ }^{\circ} \mathrm{C}$ 


\begin{tabular}{|c|c|c|}
\hline 605 & $T_{a}$ & atmospheric temperature, ${ }^{\circ} \mathrm{C}$ \\
\hline 606 & $U_{t p a}$ & overall heat transfer coefficient from plate to environment, $\mathrm{W} / \mathrm{m}^{2}-\mathrm{K}$ \\
\hline 607 & $\dot{m}_{f}$ & mass flow rate, $\mathrm{kg} / \mathrm{s}$ \\
\hline 608 & $C_{f}$ & specific heat capacity of fluid/water, $\mathrm{kJ} / \mathrm{kg}-\mathrm{K}$ \\
\hline 609 & $\mathrm{r}$ & radius of copper tube, $\mathrm{m}$ \\
\hline 610 & $T_{f o 1}$ & temperature of fluid at the outlet of first collector, ${ }^{\circ} \mathrm{C}$ \\
\hline 611 & $T_{f i}$ & temperature of fluid at the inlet of first collector, ${ }^{\circ} \mathrm{C}$ \\
\hline 612 & $T_{\text {foN }}$ & temperature of fluid at the outlet of Nth collector, ${ }^{\circ} \mathrm{C}$ \\
\hline 613 & $\dot{Q}_{u N}$ & rate of useful heat gain, $\mathrm{kWh}$ \\
\hline 614 & $A_{g}$ & area of glass cover, $\mathrm{m}^{2}$ \\
\hline 615 & $h_{1 w}$ & total heat transfer coefficient from water surface to glass cover, $\mathrm{W} / \mathrm{m}^{2}-\mathrm{K}$ \\
\hline 616 & $T_{w}$ & temperature of water, ${ }^{\circ} \mathrm{C}$ \\
\hline 617 & $T_{g i}$ & temperature at inside surface of glass, ${ }^{\circ} \mathrm{C}$ \\
\hline 618 & $T_{g o}$ & temperature at outside surface of glass, ${ }^{\circ} \mathrm{C}$ \\
\hline 619 & $A_{b}$ & area of basin liner, $\mathrm{m}^{2}$ \\
\hline 620 & $K_{g}$ & thermal conductivity of glass, $\mathrm{W} / \mathrm{m}-\mathrm{K}$ \\
\hline 621 & $L_{g}$ & thickness of glass cover, $\mathrm{m}$ \\
\hline 622 & $h_{1 g}$ & total heat transfer coefficient from glass surface to ambient, $\mathrm{W} / \mathrm{m}^{2}-\mathrm{K}$ \\
\hline 623 & $h_{b w}$ & heat transfer coefficient from basin liner to water, $\mathrm{W} / \mathrm{m}^{2}-\mathrm{K}$ \\
\hline 624 & $T_{b}$ & temperature of basin liner, ${ }^{\circ} \mathrm{C}$ \\
\hline 625 & $M_{w}$ & mass of water in basin, $\mathrm{kg}$ \\
\hline 626 & $h_{b a}$ & heat transfer coefficient between basin liner and ambient, $\mathrm{W} / \mathrm{m}^{2}-\mathrm{K}$ \\
\hline 627 & $\dot{m}_{e w}$ & hourly water yield, $\mathrm{kg} / \mathrm{h}$ \\
\hline 628 & $\mathrm{r}_{1}$ & coefficient of correlation, fraction \\
\hline
\end{tabular}




\begin{tabular}{|c|c|c|}
\hline 629 & $\mathrm{e}$ & root mean square percent deviation, $\%$ \\
\hline 630 & $r_{1}^{2}$ & coefficient of determination, fraction \\
\hline 631 & $U_{I}$ & standard uncertainty \\
\hline 632 & $\sigma$ & standard deviation \\
\hline 633 & UEOYAC & uniform end of year annual cost, Rs. \\
\hline 634 & COPW & cost of potable water, Rs. $/ \mathrm{kg}$ \\
\hline 635 & PC & present cost, Rs. \\
\hline 636 & CRF & capital recovery factor, fraction \\
\hline 637 & MC & maintenance cost, Rs. \\
\hline 638 & SFF & sinking fund factor, fraction \\
\hline 639 & $i$ & interest rate, $\%$ \\
\hline 640 & $\mathrm{n}$ & life of system, year \\
\hline 641 & SV & salvage value, Rs. \\
\hline 642 & $P_{\mathrm{u}}$ & cost of pump, Rs. \\
\hline 643 & $T_{E P B}$ & energy payback time, Year \\
\hline 644 & $F_{E P}$ & energy production factor, per year \\
\hline 645 & $\eta_{L C C}$ & life cycle conversion efficiency, fraction \\
\hline 646 & $E_{\text {in }}$ & embodied energy, $\mathrm{kWh}$ \\
\hline $\begin{array}{l}647 \\
648\end{array}$ & $h_{c w c}$ & $\begin{array}{l}\text { convective heat transfer coefficients from water surface to inside surface of } \\
\text { condensing cover, } \mathrm{W} / \mathrm{m}^{2}-\mathrm{K}\end{array}$ \\
\hline $\begin{array}{l}649 \\
650\end{array}$ & $h_{r w c}$ & $\begin{array}{l}\text { radiative heat transfer coefficients from water surface to inside surface of } \\
\text { condensing cover, } \mathrm{W} / \mathrm{m}^{2}-\mathrm{K}\end{array}$ \\
\hline 651 & $T_{w f}$ & final temperature of water, ${ }^{\circ} \mathrm{C}$ \\
\hline 652 & $T_{w f}$ & initial temperature of water, ${ }^{\circ} \mathrm{C}$ \\
\hline
\end{tabular}




$\begin{array}{lll}654 & \text { CRP } & \text { carbon dioxide reduction price, } \$ \\ 655 & \mathrm{R}_{\mathrm{i} 1} & \text { inner radius of inner cylindrical glass tube, } \mathrm{m} \\ 656 & \mathrm{R}_{\mathrm{i} 2} & \text { outer radius of inner cylindrical glass tube, } \mathrm{m} \\ 657 & \mathrm{R}_{\mathrm{o} 1} & \text { inner radius of outer cylindrical glass tube, } \mathrm{m} \\ 658 & \mathrm{Ro}_{2} & \text { outer radius of outer cylindrical glass tube, m } \\ 659 & \alpha & \text { absorptivity } \\ 660 & \tau & \text { transmissivity } \\ 661 & \alpha_{g}^{\prime} & \text { effective absorptivity of glass } \\ 662 & \alpha_{w}^{\prime} & \text { effective absorptivity of water } \\ 663 & \alpha_{b}^{\prime} & \text { effective absorptivity of basin liner }\end{array}$

664

665 References

666 Arslan M., Experimental investigation of still performance for different active solar still designs 667 under closed cycle mode, Desalination, 307 (2012) 9-19

668 Ashcroft, H., (1950), The productivity of several machines under the care of one operator. J. 669 Roy. Stat. Soc. (Lond.) Ser. B XII, 145-151

670 Bait O., Exergy, environ-economic and economic analyses of a tubular solar water heater 671 assisted solar still, Journal of Cleaner Production, 212 (2019) 630-646.

672 Bell, Stephanie, 1999. A Beginner's Guide to Uncertainty of Measurement, N0. 11, Issue 2, 673 ISSN 1368-6550, Centre for Basic, Thermal and Length Metrology, National Physical 674 Laboratory, Teddington, Middlesex, United Kingdom, p. TW11 0LW. 
675 Benson, F., (1952), Further notes on the productivity of machines requiring attention at random intervals. J. Roy. Stat. Soc. Ser. B XIV, 200-210.

677 Chapra, S.C., Canale, R.P., 1989, Numerical methods for engineers, McGraw Hill

678 Cox, D.R., (1951), The productivity of machines requiring attention at random intervals. J. Roy. Stat. Soc. Ser. B XIII, 65-82

680

681

682 683

684

685

686

687

688

689

690

691

692

693

694

Dev R., Tiwari G.N., Characteristic equation of a hybrid (PV-T) active solar still, Desalination, 254 (2010) 126-137

Dimri V, Sarkar B., Singh U., Tiwari G.N., Effect of condensing cover material on yield of an active solar still: an experimental validation, Desalination 227 (2008) 178-189

Elbar A.R.A., Yousef M.S., Hassan H., Energy, exergy, exergoeconomic and enviroeconomic (4E) evaluation of a new integration of solar still with photovoltaic panel, Journal of Cleaner Production 233 (2019) 665-680

El-Sebaii A.A., Aboul-Enein S., Ramadan M.R.I., Khallaf A.M., Thermal performance of an active single basin solar still (ASBS) coupled to shallow solar pond (SSP), Desalination, 280 (2011) 183-190

Elsheikh A.H., Sharshir S.W., Elaziz M.A., Kabeel A.E., Guilan W., Haiou Z., Modeling of solar energy systems using artificial neural network: A comprehensive review, Solar Energy 180 (2019) 622-639.

Esfahani J.A., Rahbar N., Lavvaf M., Utilization of thermoelectric cooling in a portable active solar still — An experimental study on winter days, Desalination, 269 (2011) 198-205. 
Essa F.A., Elaziz M.A., Elsheikh A.H., (2020), An enhanced productivity prediction model of active solar still using artificial neural network and Harris Hawks optimizer, Applied Thermal Engineering, 170 (2020) 115020.

Feilizadeh M., Estahbanati M.R.K., Khorram M., Rahimpour M.R., Experimental investigation of an active thermosyphon solar still with enhanced condenser, Renewable Energy, 143 (2019) 328-334.

Feilizadeh M., Estahbanati M.R.K., Jafarpur K., Roostaaza R, Feilizadeh M., Taghvaei H., Year-round outdoor experiments on a multi-stage active solar still with different numbers of solar collectors, Applied Energy, 152, (2015) 39-46

G.N. Tiwari, Solar Energy: Fundamentals, Design, Modelling and Applications, CRC Publication/Narosa Publishing House, New Delhi/New York, 2002.

Gupta V.S., Singh D.B., Mishra R.K., Sharma S.K., Tiwari G.N., Development of characteristic equations for PVT-CPC active solar distillation system, Desalination 445 (2018) 266-279

Hamadou O.A., Abdellatif K., Modeling an active solar still for sea water desalination process optimization, Desalination, 354 (2014) 1-8

Hassan H., Comparing the performance of passive and active double and single slope solar stills incorporated with parabolic trough collector via energy, exergy and productivity, Renewable Energy, 148 (2020) 437-450.

International Labor Office, (1979), Introduction to Work Study. International Labor Organization, Geneva, ISBN 81-204-0602-8. 
715 Issa R.J., Chang B., Performance study on evacuated tubular collector coupled solar stillin west texas climate, Int. J. Green Energy 14(10) (2017) 793-800.

717 J. Fernandez, N. Chargoy, Multistage indirectly heated solar still, Sol. Energy 44 (4) (1990) 215.

718

719

720

721

722

723

724

725

726

727

728

729

730

731

732

733

734

Joshi P. Tiwari G.N., Energy matrices, exergo-economic and enviro-economic analysis of an active single slope solar still integrated with a heat exchanger: A comparative study, Desalination, 443 (2018) 85-98.

Kumar B.P., Winston D.P., Pounraj P., Manokar A.M., Sathyamurthy R., Kabeel A.E., Experimental investigation on hybrid PV/T active solar still with effective heating and cover cooling method, Desalination, 435 (2018) 140-151

Kumar R, Singh D.B., Kumar N., Nirala A., Tiwari G.N., Effect of number of collectors (N) on the environment due to single slope solar desalination unit coupled with $\mathrm{N}$ identical evacuated tubular collectors, Materials Today: Proceedings, 28 (4) (2020) 2161-2165.

Kumar S., Tiwari G.N., Life cycle cost analysis of single slope hybrid (PV/T) active solar still, Applied Energy, 86(10) (2009) 1995-2004

Kumar S., Dubey A., Tiwari G.N., A solar still augmented with an evacuated tube collector in forced mode, Desalination 347 (2014) 15-24.

Nakara, B.C., Chaudhary, K.K., 2004, Instrumentation, Measurement and Analysis. Tata McGraw-Hill.

Parsa S. M., Davoud J.Y. Rahbar A., Majidniya M., Salimi M., Amidpour Y, Amidpour M., Experimental investigation at a summit above $13,000 \mathrm{ft}$ on active solar still water 
purification powered by photovoltaic: A comparative study, Desalination, 476 (2020) 114146

Rai S.N., Tiwari G.N., Single basin solar still coupled with flat plate collector, Energy Convers. Manage. 23 (3) (1983) 145-149.

S. Toyama, K. Kagakuv, Gijitsu, 24 Maruzen, Tokyo, 1972, p. 159

Sahota L. Shyam, Tiwari G.N., Analytical characteristic equation of nanofluid loaded active double slope solar still coupled with helically coiled heat exchanger, Energy Conversion and Management, 135 (2017), 308-326.

Sampathkumar K., Arjunan T.V., Senthilkumar P., The experimental investigation of a solar still coupled with an evacuated tube collector, Energy Sources Part A 35 (3) (2013) 261-270

Sandeep, Kumar S., Dwivedi V.K., Experimental study on modified single slope single basin active solar still, Desalination, 367 (2015) 69-75.

Sharshir S.W., Kandeal A.W., Ismail M., Abdelaziz G.B., Kabeel A.E., Yang N., Augmentation of a pyramid solar still performance using evacuated tubes and nanofluid: Experimental approach, Applied Thermal Engineering 160 (2019) 113997

Shehata A.I., Kabeel A.E., Dawood M.M.K., Elharidi A.M., Abd_Elsalam A., Ramzy K., Mehanna A., Enhancement of the productivity for single solar still with ultrasonic humidifier combined with evacuated solar collector: An experimental study, Energy Conversion and Management 208 (2020) 112592 
754 Shoeibi S., Rahbar N, Esfahlani A.A., Kargarsharifabad H., Application of simultaneous 755 thermoelectric cooling and heating to improve the performance of a solar still: An 756 experimental study and exergy analysis, Applied Energy 263 (2020) 114581

757

758

759

760

761

762

763

764

765

766

767

768

769

770

771

772

773

774

Singh, D.B., Dwivedi, V.K., Tiwari, G.N., Kumar N., Analytical characteristic equation of N identical evacuated tubular collectors integrated single slope solar still, Desalination and Water Treatment, 88 (2017) 41-51.

Singh D.B., Yadav J.K., Dwivedi V.K., Kumar S., Tiwari G.N., Al-Helal I.M., Experimental studies of active solar still integrated with two hybrid PVT collectors, Solar Energy 130 (2016) 207-223.

Singh D.B., Raturi A., Kumar N., Nirala A., Singh A.K., Tiwari S., Effect of flow of fluid mass per unit time on life cycle conversion efficiency of single slope solar desalination unit coupled with N identical evacuated tubular collectors, Materials Today: proceedings, 28 (4) (2020) 2096-2100

Singh D.B., Tiwari G.N., Energy, exergy and cost analyses of $\mathrm{N}$ identical evacuated tubular collectors integrated basin type solar stills: A comparative study, Solar Energy 155 (2017) 829-846.

Singh D.B., Exergo-economic, enviro-economic and productivity analyses of $\mathrm{N}$ identical evacuated tubular collectors integrated double slope solar still, Applied Thermal Engineering 148 (2019) 96-104

Singh D.B., Energy metrics analysis of N identical evacuated tubular collectors integrated single slope solar still, Energy, 148 (2018) 546-560 
775 Singh D.B., Al-Helal I.M., Energy metrics analysis of N identical evacuated tubular collectors 776 integrated double slope solar still, Desalination 432 (2018) 10-22

777 Singh G., Kumar S., Tiwari G.N. Design, fabrication and performance evaluation of a hybrid photovoltaic thermal (PVT) double slope active solar still, Desalination, 277 (2011) 399406

780

Singh R.V., Kumar S., Hasan M.M., Khan M.E., Tiwari G.N., Performance of a solar still 781 integrated with evacuated tube collector in natural mode Desalination 318 (2013) 25-33.

782 783

784 785 786 787 788 789 790 791 792 793 794

Taghvaei H, Taghvaei H., Jafarpur K., Feilizadeh M., Estahbanatia M.R.K., Experimental investigation of the effect of solar collecting area on the performance of active solar stills with different brine depths, Desalination, 358 (2015) 76-83.

Tiwari G.N., Mishra A.K., Meraj M, Ahmad A., Khan M.E., Effect of shape of condensing cover on energy and exergy analysis of a PVTCPC active solar distillation system, Solar Energy, 205 (2020) 113-125

Tripathi R., Tiwari G.N., Thermal modeling of passive and active solar stills for different depths of water by using the concept of solar fraction, Solar Energy, 80 (2006) 956-967

\section{Declaration of competing Interest}

The authors declare that there is no competing interest

\section{Availability of data and materials}

All data are given in the manuscript 


\section{Ethics approval and consent to participate}

796 Not applicable

797 Consent for publication

798 Not applicable

$799 \quad$ Funding

800 There is no funding received for the research work carried out

801 Authors Contribution

802 Sanjeev Kumar Sharma - Writing-review \& editing

803 Ashis Mallick - Writing, Formal analysis,

804 Desh Bandhu Singh- Data curation, Project administration, Software, review \& editing

805 Gopal Nath Tiwari - Review \& editing 
Figures

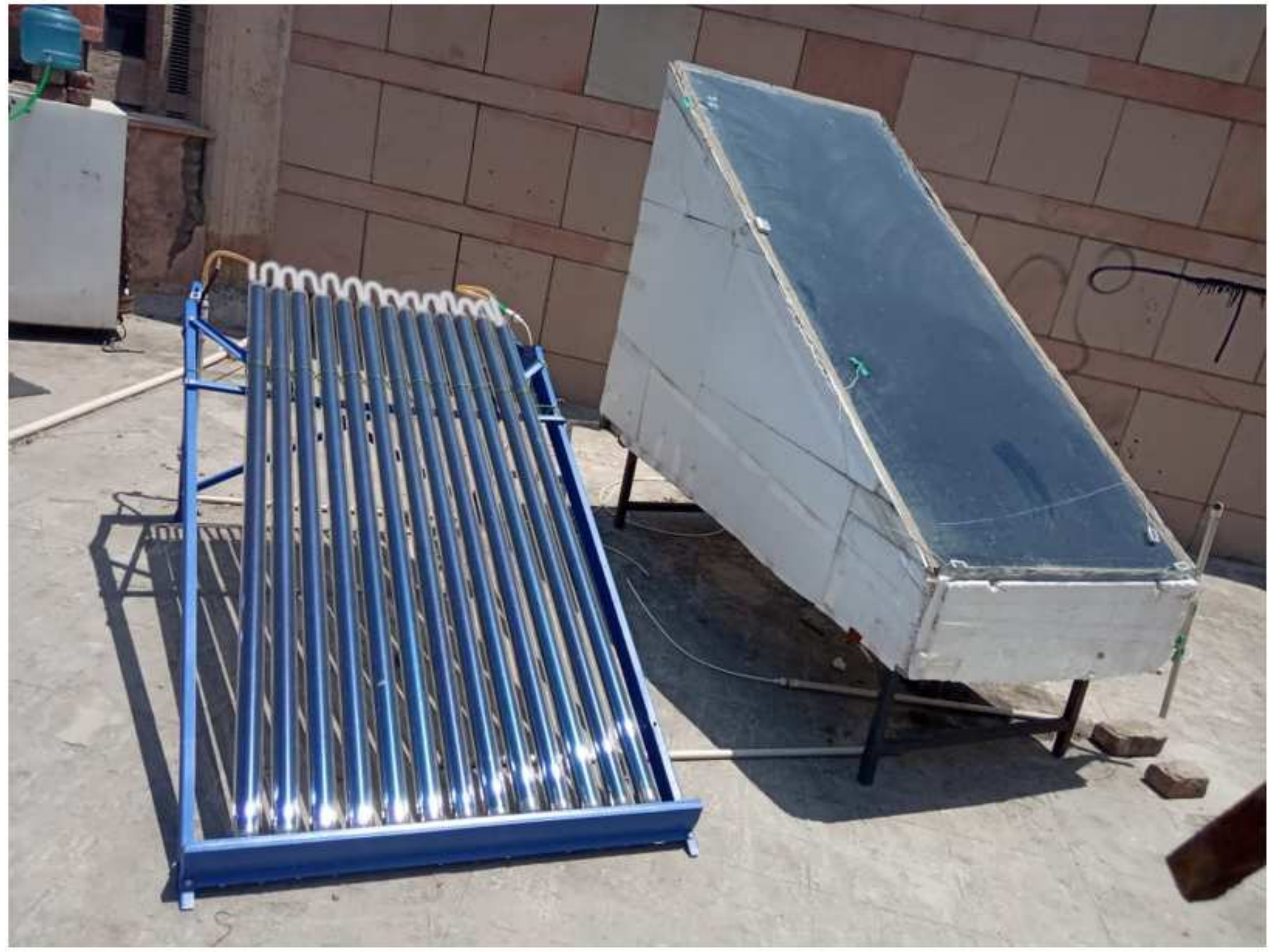

Figure 1

Experimental setup of SEBWP of single slope type integrated with evacuated tubular collectors 


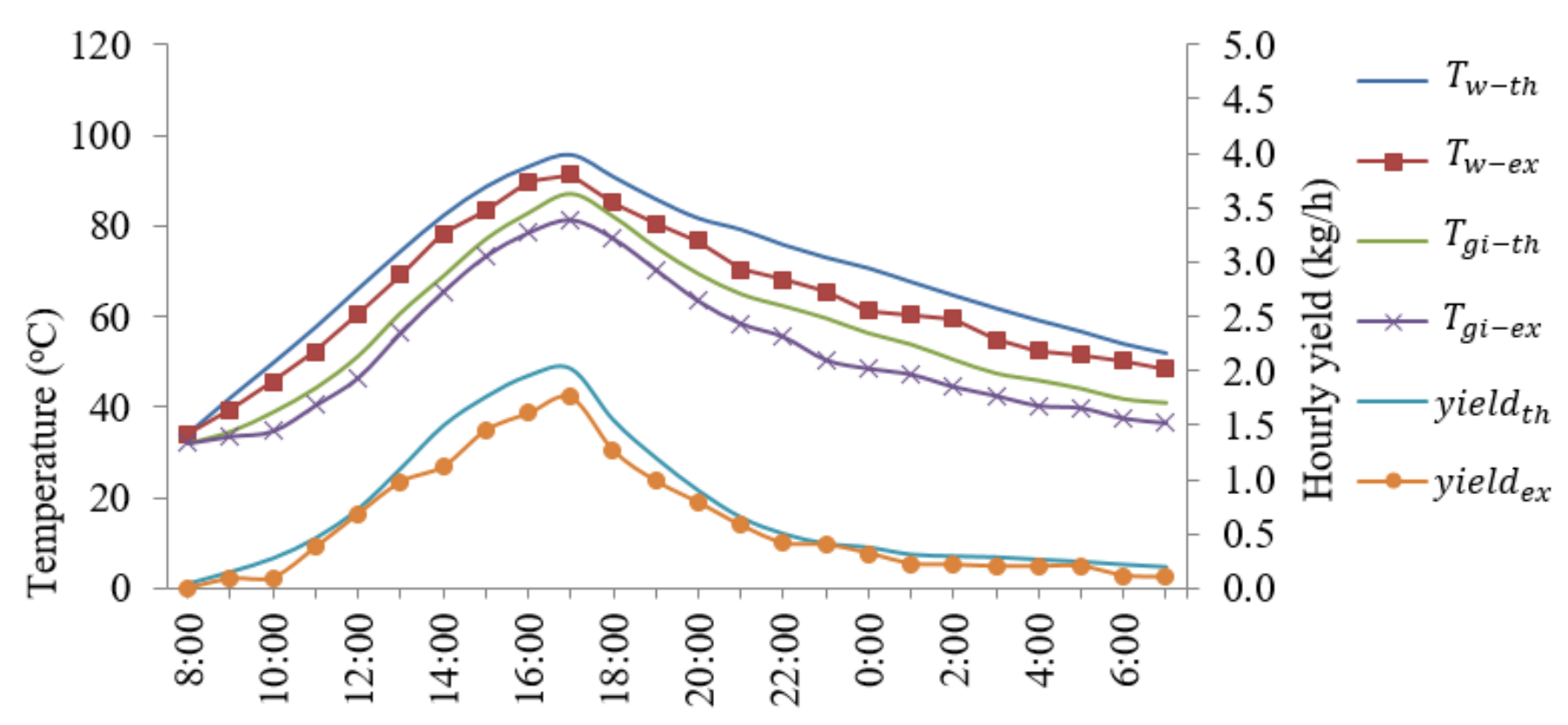

Time (h)

Figure 2

Validation of values of Tw, Tgi and hourly yield on April 29, 2019 for SEBWP of single slope type integrated with evacuated tubular collectors

$\Delta$ Daily exergy $\quad$ Monthly exergy $\Delta$ No. of clear days

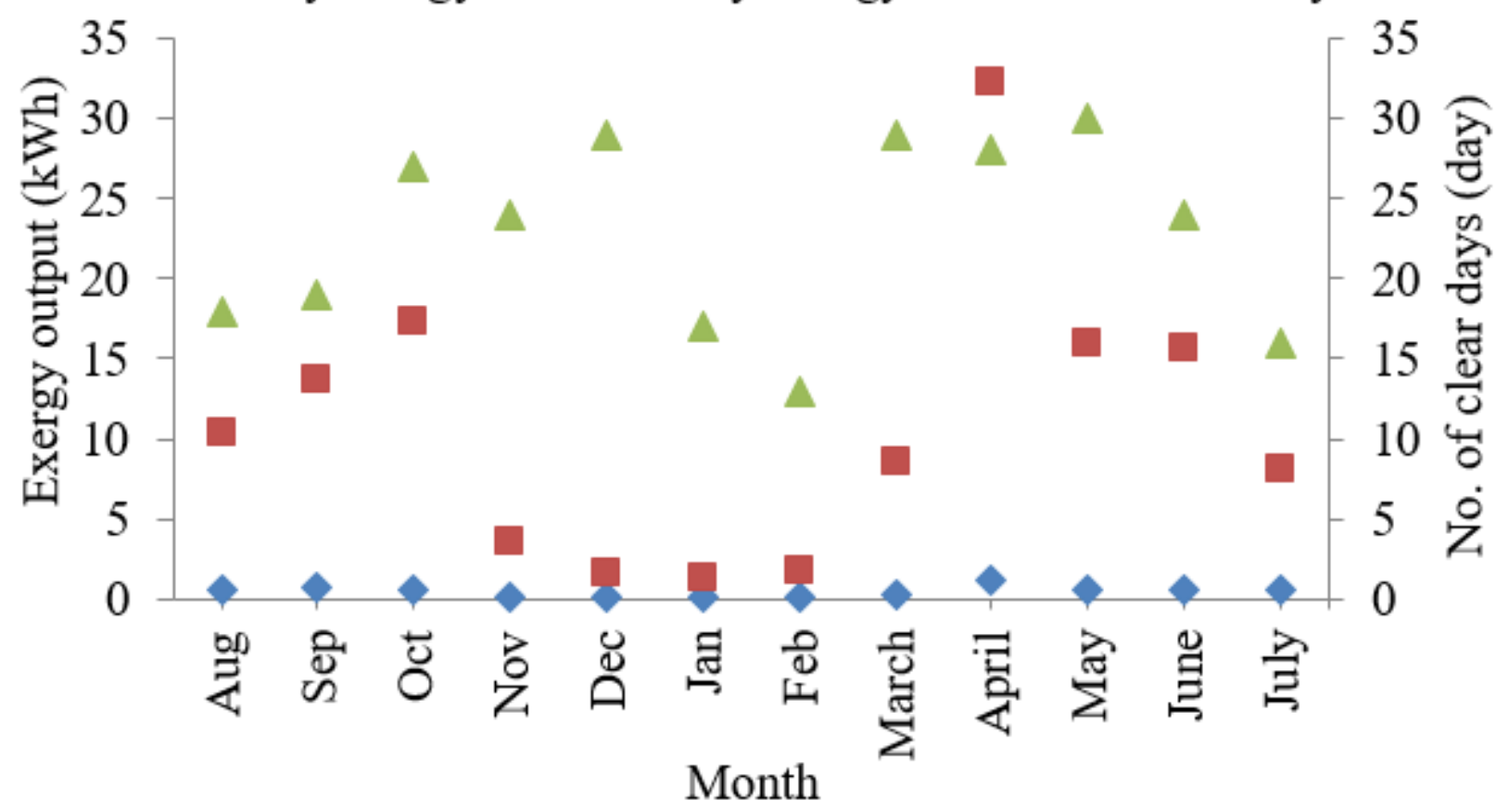

Figure 3 
Variation of monthly exergy output for SEBWP of single slope type integrated with evacuated tubular collectors

Daily solar energy $\Delta$ Monthly solar energy $\|$ No. of clear days

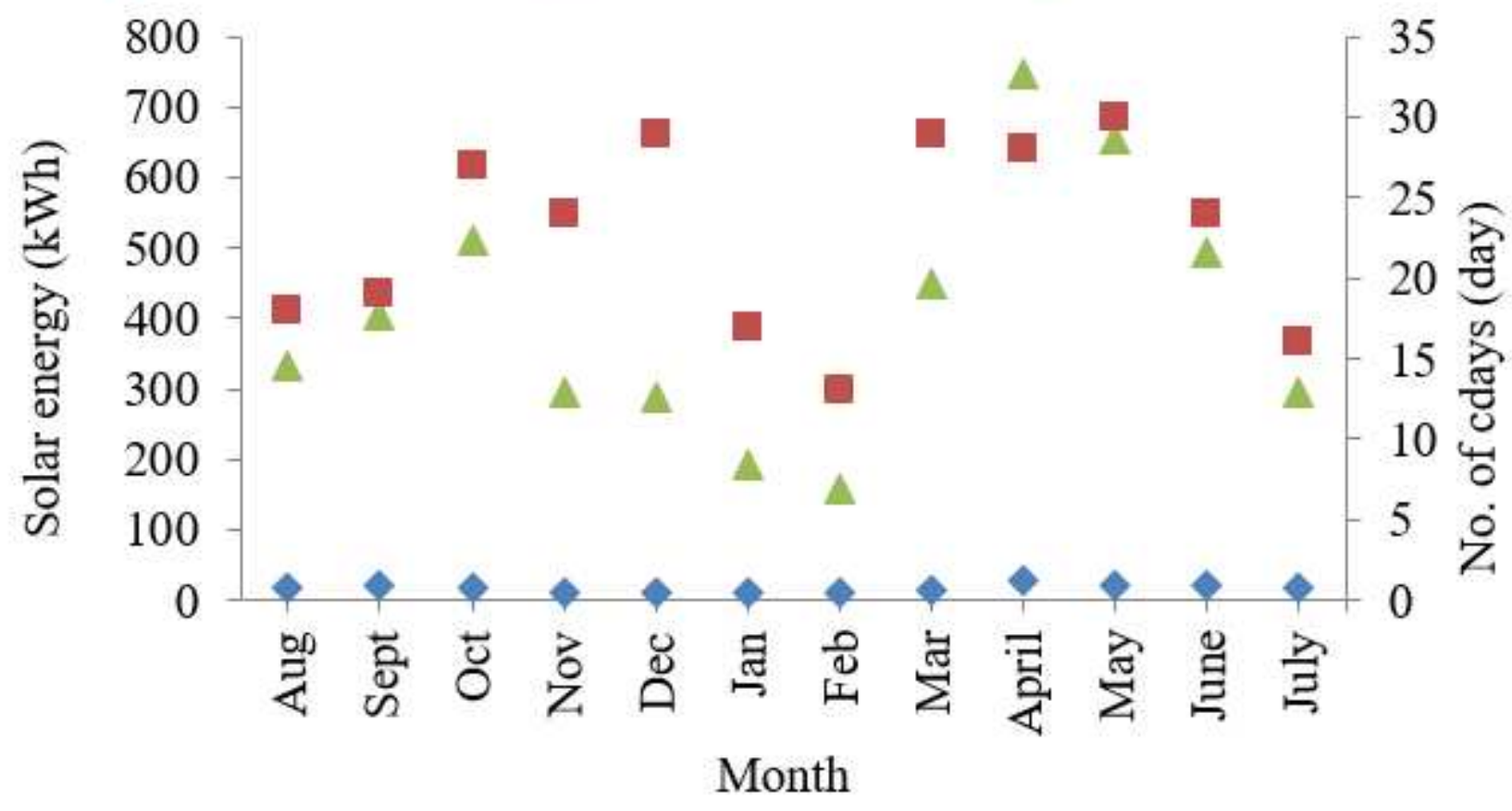

Figure 4

Variation of monthly solar energy falling on the surface of SEBWP of single slope type integrated with evacuated tubular collectors 


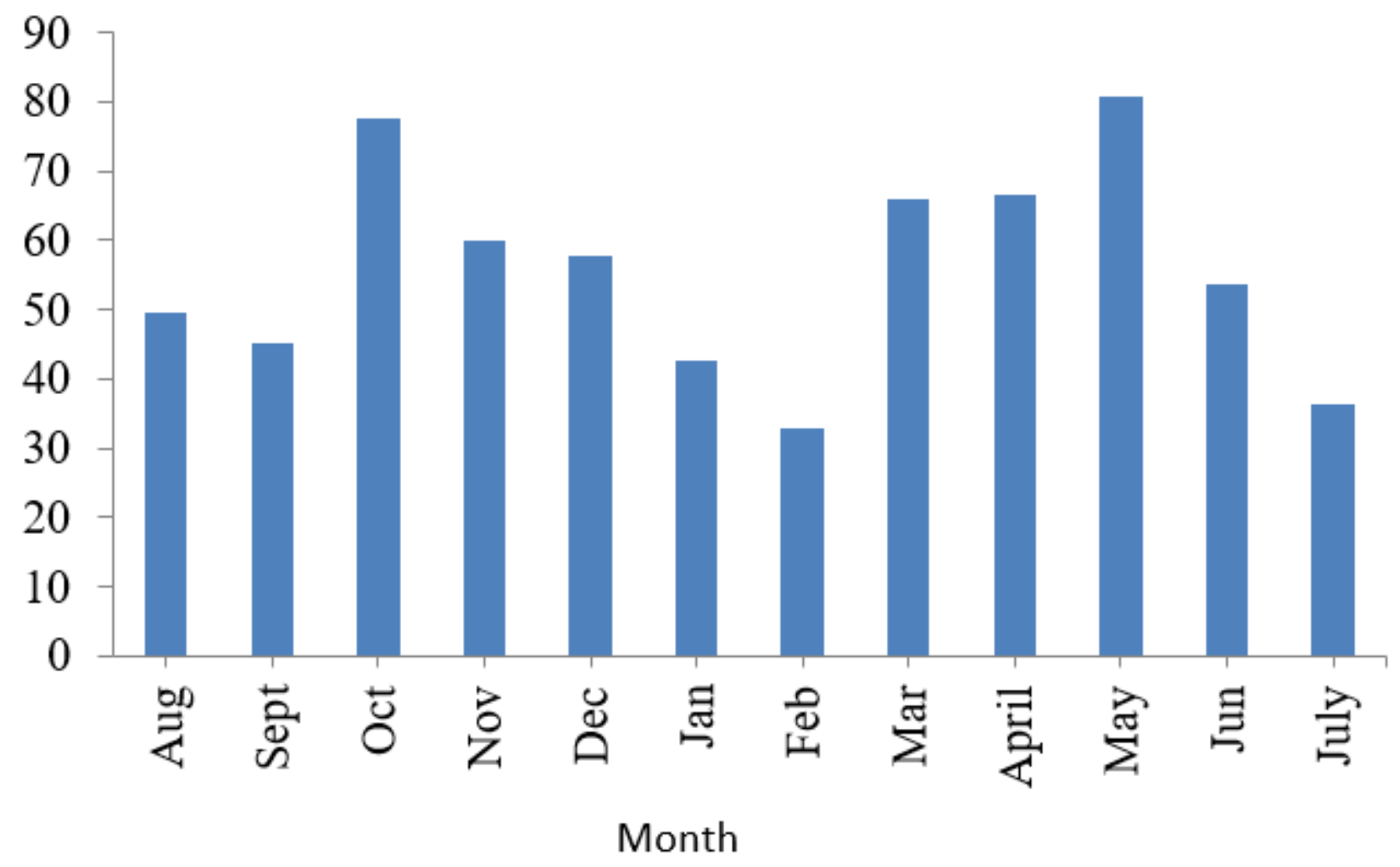

Figure 5

Variation of monthly exergy loss for SEBWP of single slope type integrated with evacuated tubular collectors 